\title{
Article \\ Energy Innovation of Polish Local Governments
}

\author{
Sławomir Stec ${ }^{1, *(1)}$ and Elżbieta Jadwiga Szymańska ${ }^{2}$ (1) \\ 1 Departament of Economics, Faculty of Management, Rzeszow University of Technology Ignacy Łukasiewicz, \\ 35-959 Rzeszow, Poland \\ 2 Department of Logistics, Institute of Economics and Finance, Warsaw University of Life Sciences-SGGW, \\ 02-787 Warsaw, Poland; elzbieta_szymanska@sggw.edu.pl \\ * Correspondence: s.stec@prz.edu.pl
}

check for

updates

Citation: Stec, S.; Szymańska, E.J.

Energy Innovation of Polish Local

Governments. Energies 2022, 15, 1414.

https://doi.org/10.3390/en15041414

Academic Editor: Kostas Kounetas

Received: 30 December 2021

Accepted: 11 February 2022

Published: 15 February 2022

Publisher's Note: MDPI stays neutral with regard to jurisdictional claims in published maps and institutional affiliations.

Copyright: (C) 2022 by the authors. Licensee MDPI, Basel, Switzerland. This article is an open access article distributed under the terms and conditions of the Creative Commons Attribution (CC BY) license (https:// creativecommons.org/licenses/by/ $4.0 /)$.

\begin{abstract}
The main aim of the research is to evaluate the innovativeness of Polish municipalities in the field of energy. The study was carried out as a part of the First National Competition for the Most Innovative Local Government in Poland, taking into account the original method of assessing the innovativeness of local governments. From all over Poland, 30 communes participated in the research: 14 urban communes, 8 rural communes, and 8 urban-rural communes. The study analyzes the activities of municipalities in the field of energy-related construction and transport innovations and inventories innovative social campaigns in the area of climate and energy policy implementation. The second part of the article presents a case study of innovations recognized as exemplary. As a result of the conducted research, it was found that $50 \%$ of the surveyed local governments are innovative and the remaining are moderately innovative. No commune has been assigned to the non-innovative category. In terms of the type and size of the local government, it has been observed that smaller municipalities, mainly rural local governments, allocate much higher financial resources per capita to the implementation of modern solutions in the field of climate and energy policy implementation. In some cases, commune heads spend several times higher funds per capita than mayors and city presidents. The use of the developed innovation research method in practice may motivate local government authorities to increase innovative activities for energy transformation.
\end{abstract}

Keywords: energy policy; investments; economic assessment; costs and benefits; local development; renewable energy sources

\section{Introduction}

Natural disasters and ecological catastrophes are derivatives of unfavorable climate changes caused by human activity. The most unfavorable change, however, is global warming, which is currently estimated at $1.0^{\circ} \mathrm{C}$ above pre-industrial levels. It is predicted that with the current growth trend, global warming is likely to reach $1.5^{\circ} \mathrm{C}$ in 2030-2052 [1]. Therefore, many initiatives are taken to effectively contribute to limiting this unfavorable phenomenon and, above all, to change the climate and energy policy. One of such initiatives is the cyclical Conference of the Parties to the UN Convention (COP26) on climate change, which has been organized for the last 30 years. At this conference, the leaders of all countries of the world meet to intensify global efforts to solve the climate crisis. During the last edition of COP26, which took place from 31 October to 13 November 2021, in Glasgow, the following initiatives were established:

- Bigger commitments to provide funds to developing countries to help fight climate change;

- Adoption of a global commitment on methane;

- $\quad$ Finalization of the Paris package [2].

The aforementioned Paris package is an effect of the so-called Paris Agreement of 2015, under which all EU countries have signed and ratified a document that stipulates that by 2050 , the EU will be the world's first economy and the world's first society to achieve 
neutrality of the climate and by 2030 will reduce EU greenhouse gas emissions by at least 55\% compared to 1990 levels [3]. Consequently, in December 2019, the "Ready for 55" package was developed, an initiative of the European Green Deal that includes, among others, the following:

- $\quad$ Change in the EU Emissions Trading System (ETS);

- $\quad$ Effort Sharing Regulation;

- The Renewable Energy and Energy Efficiency Directive;

- Ordinance on land use and forestry;

- The regulation on $\mathrm{CO}_{2}$ emissions from passenger cars and delivery vehicles [4].

The European Green Deal is a communication from the European Commission that proposes changes to European Union law in order to increase the level of environmental and climate protection. Out of the proposed nine actions, attention should be paid to the demand to develop more ambitious EU climate goals for 2030 and 2050, as well as to deliver clean, affordable, and safe energy. A significant element is also an initiative leading to a reduction in pollutant emissions and activities related to sustainable and intelligent mobility [5].

These priorities will contribute to accelerating the global transformation toward a low-carbon economy. Following the EU guidelines, but also with care for the immediate environment, the governments of individual countries as well as city and communal authorities, or the companies themselves, are already allocating large amounts of funds to green energy. However, many of these activities require further development. First of all, modern solutions that can be obtained thanks to technological progress are needed. Therefore, the innovation implementing process should be intensified and entities responsible for the implementation of climate and energy policy should become more innovative. It is thanks to innovation that ideas and knowledge are transformed into modern products and services, which in turn help solve many critical problems, including social threats, and increase the ability of society to take intensified action. The result of innovation is economic growth, improved welfare and communication, and, above all, sustainable environment development. Nowadays, innovations are implemented in every area of life, sector, or industry branch. Innovations can be found in medicine, IT, electrical engineering, mechanics, agriculture, and the energy sector as well. Modern and improved technologies are used in the everyday functioning of towns and villages. Thus, a wide range of innovations, as well as their ubiquity, can play an important role in the energy transformation of the world.

However, it is important that all innovative activities in the field of climate and energy policy creation are carried out at every administrative level, in particular at the local and regional levels. It is in the so-called small homelands, i.e., at the level of municipalities, that the implementation of energy innovations contributes most to environmental protection. It should also be noted that in many cases, it is up to local governments to decide what actions they will undertake in this regard. Municipalities own many public utility buildings and administer municipal flats, which is why they are responsible for supplying electricity and heat, and create local climate and energy policy. Local governments also organize public transport and are also responsible for the infrastructure supplying energy to end users.

In recent years, there has been a growing interest in energy innovation at the local level and, in particular, in the use of renewable energy sources in municipalities. More and more local governments take actions that contribute to the creation of a new energy policy, thanks to which they strive to improve the condition of the environment and the quality of life of residents and, above all, reduce the costs incurred. Research in this area is the most advanced in the Scandinavian countries (Denmark, Sweden, and Norway), Germany, and the United States, i.e., in the countries the level of advancement of energy innovations is the highest. Most often, however, research in this area concerns a review of the climate and energy policy of cities and villages and strategic planning. There is little research on measuring the level of energy innovation, especially at the level of local governments. An example is the Global Energy Innovation Index (GEII) of the Information Technology and Innovation Foundation (ITIF) of 2021, which provides a multifaceted 
assessment of countries' contributions to the global innovation system in the field of energy. The research methodology is based on the application of 20 indicators, including the level of public investment in clean energy research and development. The study covers 34 countries [6]. However, the Global Cleantech Innovation Index (GCII) defines the system of clean technology innovation in 40 countries. In this case, the outlays correspond to the creation of innovations and the results relate to the country's ability to commercialize innovations. However, the research results refer to the level of the whole country [7].

A study of cities in the field of energy innovation was carried out by the Belgian Heinrich Böll Stiftung, which carried out a study entitled "Cities: Testbeds for Energy innovation". As part of the research, the largest cities of the European Union were analyzed in the field of implementing innovative tools and solutions in the field of energy in order to limit climate change [8]. Kightlinger, however, made a financial analysis of sustainable energy projects implemented by various cities around the world. The research allowed formulating the conclusion that with adequate financial resources, cities can become leaders in transformation in energy generation and implementation of innovative projects [9].

The United States conducts a quarterly analysis among local governments using green energy, the so-called Green Power Partnership Top 30 Local Government. The basis of the prepared ranking is the percentage share of green energy in the total electricity consumption [10].

In 2019, the World Resources Institute conducted a study of American cities on the use of modern solutions in the field of energy transformation. In this way, several creative ways have been developed that cities use when switching to renewable energy as role models for others [11].

The use of renewable energy in cities and trends in this area are also covered by the latest REN21 Renewables in Cities Global Status Report, published by the World Economic Forum [12]. In 2018, WSP produced the Top 10 Cities in Power Generation and Distribution report, which outlined 10 leaders in energy innovation in the world [13]. A similar topic was dealt with by Began, who in 2020 developed a ranking of eight innovative cities using technology to reduce energy consumption. The ranking includes three cities from North America and five cities from Europe [14].

Collier and Löfstedt analyzed the activities of six municipalities in Sweden and the United Kingdom. The research made it possible to compare the activity of local authorities of the two countries in the field of energy efficiency and the creation of climate and energy policy [15].

Nordic Energy Research published a report in 2020 entitled "Tracking Nordic Clean Energy Progress", which presents Scandinavia's progress toward a carbon-neutral society, highlighting key trends and analyzing scenarios in which Nordic solutions can have a global impact [16].

Anderson, Ödlund, and Westling conducted a study on the activities of Swedish local governments in the implementation of sustainable clean energy policies and the implementation of innovative tools. They concerned three areas: the activities of municipalities toward citizens and the business community, the activities of municipalities for cooperation with other entities, and the challenges associated with these activities [17].

Research on innovation is also carried out by the OECD. In the study entitled "Public Sector Innovation Scan of Denmark", you can find data on the implementation of modern solutions for the energy transition by Danish local governments [18]. Valuable conclusions for this country were also developed by experts from Aarhus University, who carried out research in all Danish municipalities and presented case studies of selected local governments. On their basis, they showed that local governments have the most tools and financial resources to implement energy innovations [19].

The best practices in the transition to a low-carbon economy among local governments in Germany and the Netherlands were presented by Hoppe and his team. On the basis of in-depth interviews and empirical data, they developed the most effective strategies in the implementation of modern solutions [20]. 
In the case of Poland, research concerns the importance of innovation, the conditions for its application, or general considerations on this topic. There are also analyses of the level of expenditure on research and development in the energy sector. From 2005 to 2012, the National Energy Conservation Agency S.A. conducted the Competition for the Most Energy-Efficient Commune in Poland. As the basic indicator, the energy consumption per kWh was used [21]. The Polish Press Agency has been running a cyclical Competition for an Innovative Local Government since 2020, in which one of the examined elements is the measurable ecological result of the implemented innovation (e.g., reduction of dust emissions by a certain amount). Unfortunately, however, the detailed results of this competition are not available. However, it should be emphasized that in the indicated competition, the communes selected for the study are similar to the ones used in this study, as local governments apply voluntarily [22]. There is also a study entitled "The 30 Most Active Municipalities in the Clean Air Program", which analyzed the number of applications submitted in a given local government for activities related to the elimination of obsolete furnaces that emit significant amounts of $\mathrm{CO}_{2}$ [23].

As can be noticed, there is a significant research gap in the field of comprehensive research among local governments in the innovative activities field for the implementation of climate and energy policy, including measurable aspects.

Therefore, the authors attempted to examine the level and scope of innovation in the area of climate and energy policy implemented by Polish local governments. The main objective of the article is to evaluate the level of energy innovation of Polish local governments and to make an inventory of energy innovations carried out for the implementation of the climate and energy policy. The analysis covered Polish local governments due to the lower level of their innovation in relation to municipalities from countries such as Denmark, Sweden, Norway, or the United States. At the same time, Poland is obliged to carry out energy transformation and according to the research of other authors, these changes are best implemented at the local level. In addition, local authorities often draw on the knowledge and experience of other local governments in the design and implementation of energy innovations. On the basis of the analysis of the literature on the subject, one can notice a dispersion within the systematization of tools used to assess the level of energy innovation of local governments. Therefore, there are reasons to conduct a comprehensive study of the level of innovation of municipalities and to disseminate the developed research results. As a part of the research, the activities of municipalities in the field of energy-related building and transport innovations were analyzed and innovative social campaigns in the implementation of climate and energy policy were inventoried. Based on the expenditure of municipalities within individual areas (construction investments, transport investments, social campaigns, and innovative projects), using the proprietary method, local governments were categorized in terms of the level of innovation. At the end of the study, a case study of the best innovations in four municipalities was presented, which, following the developed methodology, were considered to be exemplary. The research was carried out as part of the First National Competition for the Most Innovative Local Government in Poland, in which 30 communes from all over Poland participated.

To achieve the set goal, the following structure is used in the article: The first part presents theoretical considerations on innovation and energy innovation at the local government level. Then, the method of evaluating innovations implemented in municipal self-governments and the method of interpretation of the achieved results are described. The next part presents the level and scope of energy innovations, i.e., the results of the conducted research are presented. Based on a case study, the best practices of local governments are described as part of the implemented innovations in different areas, such as innovations in the field of energy construction investments and energy transport investments and social campaigns in the field of promoting knowledge about energy. 


\section{Innovation and Energy Innovations in Local Governments: Theoretical Considerations}

Innovation is a concept that is well known, and it was first introduced to economic sciences by Schumpeter in 1912. He identified six types and innovations:

- $\quad$ Producing new products or improving existing ones;

- Using new methods of production;

- Opening a new sales market;

- Creating a new type of product;

- Acquiring new sources of raw materials or semi-finished products;

- $\quad$ Establishing a new industry organization [24].

Innovations, in this approach, include technological, economic, and organizational changes occurring in the entrepreneurship process, which indicates the product, process, and organizational nature of innovative activities [25]. In the years following 1912, the concept of innovation evolved, but it was mostly associated with changes and originality became their characteristic feature [26]. According to Freeman, innovation is the first commercial application of a new product, process, or device [27]. However, according to Jashapar, innovation means not only creating something new but also making corrections, improvements, and certain changes that contribute to recognition by the organization as something new and progressive [28].

A commonly used definition of innovation is the one published in 2005 in the Oslo Manual, which defines the concept of innovation as bringing new or significantly improved products to the market or finding better ways (through new or significantly improved processes and methods) to bring products to the market [29]. The latest edition of the Oslo Manual (2018) further specifies the concept of innovation and innovative activity, but in the field of the enterprise sector. It is indicated that a business innovation is a new or improved product or business process (or a combination thereof) that differs significantly from previous products or business processes of the enterprise and that has been introduced to the market or put into use by the enterprise. Innovative activities include all developmental, financial, and commercial activities undertaken by an enterprise leading to the creation of innovation for the enterprise [30]. In the context of the presented definitions of innovation in local governments, the authors of Oslo Manual (2018) emphasize that innovation at the municipal level is often based on political and social premises and is related to profit maximization and does not achieve business goals. Often, innovations are created in collaboration with other sectors and are created as a part of co-creation [30]. Sometimes, they are created as public-private partnerships if local governments invite small and medium-sized enterprises to cooperate and if they display scientific research presenting innovative projects [31]. Innovations in local governments, as Chądzyński points out, are activities leading to the search for new, better solutions in a given territory that lead to specific changes [32]. However, in the opinion of Marciniak, innovations in local governments are creative changes in the social system, the economic structure in technology, and the natural environment, while maintaining their good condition [33]. All innovative activities have the following features:

- The developed changes should find practical application.

- The changes should result in determined technical, economic, and social benefits.

- Innovations are a positive change in the current state.

- Innovations are a carrier of technological progress.

- Innovation results in the development of entities, economic organizations, local governments, and entire societies.

- Innovation should be in the form of continuous improvement [34].

The term "innovation" is associated with the concept of innovativeness. In literature and everyday life, these two terms are often used interchangeably, which is not correct. So, innovativeness is the ability to create new solutions in various spheres and sectors as well as a product or a service. Innovativeness consists in implementing an element of novelty or 
improvement, which means building a product, a service, or a situation from the beginning or implementing a given solution for the first time, and the result of the innovative process (innovativeness) is innovation [25]. According to Łyżwa, innovativeness is the ability to generate and introduce new technical, organizational, and social solutions to the global market [35]. Innovative activity, however, is the process of developing innovation through scientific, technical, organizational, financial, and commercial activities. Some of them are innovative in themselves. Others are not a novelty but are necessary for the implementation of the innovation. Innovative activity is related to research and development (R\&D) activity, which is necessary to develop any innovation [36].

As is apparent from the given definitions, innovations in local governments are developed and implemented at various levels and in different circumstances; therefore, various types of innovations can be identified. At the local and regional levels, these are as follows:

- Institutional and organizational innovations, which boil down to public management, regional innovation systems, and city marketing;

- Product innovations related to multi-functional spaces, urban transport, technology parks, etc.;

- Technical and technological innovations, which include IT processes but also those related to energy and other municipal networks;

- Innovation in financial management, including public-private partnership [37].

Currently, most local government authorities try to carry out innovative activities and create and implement innovations in various areas in which they are allocated competencies. Therefore, innovations can cover the following areas:

- $\quad$ Elements of technical infrastructure (transport networks, energy networks, sewage networks, heating networks, telecommunications, and IT connections);

- Elements of social infrastructure (public utility buildings, schools, community centers, health centers, and offices);

- Methods of obtaining electricity and heat;

- Natural environment (climate, parks, forests, squares, reservoirs, and watercourses);

- Outbuildings (buildings and structures for conducting business activities);

- $\quad$ Elements of tourist infrastructure and tourist services;

- Real estate management;

- Administrative services;

- Consumer services;

- $\quad$ Society (the everyday life of the inhabitants) [38].

Local governments can develop and implement innovations within individual areas, or they can apply them comprehensively, which is why in many cases individual spheres of activity are related to each other. An example is conducting joint innovative activities in the implementation of climate and energy policy, which will associate areas related to technical infrastructure, social infrastructure, methods of obtaining energy, and activities for the benefit of the natural environment. To some extent, such activities may also affect other spheres of activity of municipal offices. Innovations in the energy sector arise from the necessity to intensify modern actions for the climate at every administrative level and in every area of management.

Therefore, in 2017, the Ministry of Energy published a document entitled "Innovations for energy. Directions for the development of energy innovations". Among the four directions of development of energy innovations, the last one is the ecological and energyefficient city. Within its framework, three areas of activity have been identified. The first one concerns the modernization of individual heat sources and its aim is to significantly improve air quality. Another area is the development of cogeneration and heat/cold transmission networks, under which the implemented innovations will contribute to the reduction of primary energy consumption in the balance of individual systems and the entire country. The last area is reducing the energy consumption of buildings. Activities in this area 
aim to reduce the energy consumption of buildings and to introduce innovative business models and tools motivating users to use the potential of increasing the energy efficiency of buildings. It is worth noting, however, that in the other three areas of innovation development, measures can be found that are the responsibility of local authorities. These include tasks related to the development of electro-mobility (popularization of electric transport) and increasing energy recovery from waste, especially in connection with the production of energy and heat [39].

Another document indicating the need for the development of innovativeness in cities is the study entitled "Polish Cities of the Future 2050", which presents model scenarios that are to contribute to the intensification of activities for the sustainable development of municipalities. Most of these activities are both product and organizational innovations. Among them, there are many innovations aimed at implementing the climate and energy policy. Among the most important, there are:

- Solutions improving access to daylight, ensuring temperature regulation, as well as reducing the electricity used to illuminate rooms with artificial light;

- Use of green roofs, terraces, and walls and the integration of greenery with buildings;

- Use of smart home and smart building solutions as well as the Internet of Things;

- Construction of zero-emission buildings and adapting the existing ones to energy self-sufficiency;

- Implementation of solutions allowing for energy storage;

- Use of recycled materials in the construction of facilities and buildings;

- Promotion of remote work, which reduces the movement of people between home and workplace;

- Application of solutions contributing to water saving, including small retention;

- Implementation of zero-emission and low-emission vehicles as well as autonomous vehicles in transport;

- Increased use of energy from renewable energy sources [40].

Technological and system innovations play a significant role in energy transformation, especially in its early stages. The implemented R\&D works may contribute to lowering costs, improving efficiency, and adapting solutions to local conditions. According to the opinion of the International Renewable Energy Agency, innovations must go beyond the technological framework of R\&D and the improved technology must be used in business models, local government policies and strategies, processes, and market projects. Priority must be given to innovations in the use of transport, industry, and construction. Such innovations should include increased electrification of end uses using renewable energy sources. In addition, modern technologies in the field of digitization of network services; energy storage; intelligent charging of electric vehicles; as well as small, local energy networks should be used. The private sector should also be involved in the process of implementing innovations by implementing joint initiatives by establishing publicprivate partnerships.

Innovation in power engineering is driven by the need to combat climate change, increase access to affordable and safe energy, and increase the use of renewable energy sources, as well political, social, and market needs [41].

A significant role in improving the implementation of energy innovativeness is played by their inclusion in long-term strategies at the national and local levels. Importantly, they do not have to be innovations in the energy sector only but need to be implemented in other areas, especially those related to climate change and the environment as well as R\&D support. It is important to support innovation stimulus measures [42].

In Polish and foreign literature, energy innovations mainly boil down to modern methods of energy production and storage. Okraszewska points out that energy innovations focus on unconventional renewable energy sources, such as wind and sun. Additionally, innovations in energy production concern the search for newer and newer renewable resources, as well as new ways of using already known sources [43]. Zawada et al. mention a similar approach to energy innovation [44]. The authors emphasize that innovations in 
the energy sector occur in the field of production, storage, transport, and environmental protection. In the case of production, innovations mainly concern the acquisition of energy from renewable sources, such as wind, solar, water, and biomass. Added to this is geothermal energy. However, according to the authors, solar energy is of the most importance. Innovations in the energy storage field are also important, as the increasing worldwide energy gain from renewable sources is often associated with unfavorable weather conditions and temporary shortages of these sources. Therefore, modern energy storage devices in the form of accumulators of various types, high-power rotating disks, superconducting coils, electrolytic capacitors, and pumped storage power plants are built and installed [45].

Energy innovations in the transport sector concern increasing energy efficiency through modern technical solutions involving the use of alternative fuels. Even at the beginning of the 21st century, a breakthrough innovation was the spread of low-emission technology in the form of the use of LNG and CNG (natural gas) to supply means of transport. This technology is already common, but many local governments consider it modern. Of course, such solutions can then be treated as innovations at a local scale. Currently, innovations on a larger scale are the implementation of zero-emission solutions in transport, i.e., the use of electricity and hydrogen to power vehicles [44].

When considering innovations in the energy sector, innovations in building intelligent energy networks that contribute to increasing efficiency, reducing energy consumption, and reducing greenhouse gases cannot be ignored. Such solutions include tools for the optimal management of the distribution network, instruments for advanced technical calculations based on statistical and dynamic data, as well as activities contributing to the removal of barriers to the development of distributed generation sources, including RES energy production. Control and regulatory processes in the field of voltage and reactive power levels as well as the implementation of mechanisms of active influence on the demand of energy consumers are also worth noting [44].

In Denmark, a country considered to be a leader in European and global energy innovation, energy innovations are also processes involving the implementation of modern methods of obtaining energy from renewable sources, e.g., from wind [46].

According to Portuguese experts, only technical innovations in the energy sector are insufficient. They believe that for the effective implementation of innovations for energy transformation, actions should be planned considering spatial planning and the main entities that will play the most important role are local governments [47].

A much broader approach to energy innovation occurs in Sweden, which is another country where such innovations are most widespread. In this country, it is believed that the implementation of each novelty in the energy sector must be associated with social challenges that will contribute to reducing greenhouse gas emissions. Moreover, the elements shaping energy innovations are actions for energy and resource efficiency, urbanization, demographic change, and global industrial competitiveness. Energy innovations themselves are treated in terms of areas and concern technological, social, and digital innovations in the field of power systems, energy-efficient transport, energy-efficient and intelligent buildings, the use of sustainable thermal processes, and the efficient use of energy in industry (or their decarbonization) [48].

A similar approach to energy innovation is used in China. In Asia, as in Europe, the most important energy innovations include activities in the field of clean energy production, mainly the use of solar cells (PV) and the development of electric vehicle (EV) technologies [49].

From a formal point of view, regardless of the field, area, or sector in which innovations are intended to be implemented, they should be patentable or obtain a utility model. It is a compelling argument that innovation has been developed [50].

Based on the analyses, it can be concluded that in Poland or other European countries, as well as in China and the United States, the approach is similar. Everywhere, energy innovations are treated as activities consisting in the development and implementation of 
technologies and processes in the field of renewable energy sources, the dissemination of the use of zero-emission technology in vehicles, as well as the pursuit of energy efficiency.

However, the actions of national governments in the field of innovation are not always effective. Often, one notices social dissatisfaction with the slowness of the central authorities in implementing modern solutions accelerating actions for the climate. Therefore, more and more often, civil society, sometimes supported by local self-governments, develops its own local initiatives. The motivations to create local social initiatives are ecological issues (mitigating climate change, protection of natural resources, etc.), as well as economic and social aspects (a sense of community, making life in the city and the countryside more attractive). Grassroots civic initiatives often relate to social actions, thanks to which the awareness of residents in the field of energy transformation is raised. These actions may include protesting against outdated and environmentally unfriendly energy use, lobbying for energy-innovation-oriented actions, stimulating green consumption, and supporting environmental education [20].

\section{Materials and Methods}

Measuring the effects of innovation is, however, a problem. This is because most innovations and innovation activities take into account political and social aspects. There is virtually no market in this case, and all effects of this activity are based on subjective, self-reported indicators, such as increased productivity or increased user satisfaction [30]. In practice, many methods of measuring innovation have been developed, which are used, among others, for rankings and comparisons. The most common is the so-called Oslo methodology, based on the guidelines that relate to statistical surveys of technological innovations carried out using the method of the subject. The research covers the enterprise sector, industry, and the market services sector [30].

Another commonly used method of measuring innovation is the statistics-based Community Innovation Survey. It measures innovation in European science and technology. Research is carried out there every 2 years, and the source of data surveys based on which general information is collected is the innovative activity of an organization, expenditure on $R \& D$, the impact of innovation on the results of activity, sources of information on innovations, methods of intellectual property protection, or barriers in implementation [51].

The indicated methods relate mainly to the measurement of enterprises' innovativeness. In the case of measuring innovation for national administrative units, the Oslo method is mainly used. However, it is difficult to find in the literature an individual method of measuring innovation in local governments at the commune level, especially those narrowed down to measures related to the implementation of the climate and energy policy. Therefore, for the research that was a part of the evaluation of local governments in the National Competition for the Most Innovative Energy Local Government, an original method of measuring energy innovation in Polish municipalities was developed. During its development, the Oslo methodology and the Community Innovation Survey method were partially taken into account.

The developed method of measuring energy innovation in communal self-governments consists of two parts. The first part concerns the expenditure of communes per capita on innovative activities in specific areas and includes:

(a) The level of expenditures per capita allocated to energy construction investments in a given year, in which the local government is the investor;

(b) The level of expenditure per capita allocated to energy transport investments in a given year;

(c) The level of external funds spent per capita by the commune for the implementation of the climate and energy policy in a given year;

(d) The level of expenditure per capita of the local government on social actions related to the implementation of the climate and energy policy in the commune in a given year.

In relation to the above-mentioned criteria, the method of converting the outlays in individual areas into points was applied according to the following formulas: 
(a) Energy construction investments $\left(I_{B I}\right)$ :

$$
I_{B I}=\frac{C_{B x}}{C_{B \max }} \times 10
$$

where $C_{B x}$ is the level of expenditure per capita allocated to energy construction investments in the commune in a given year and $C_{B \max }$ is the highest level of expenditure per capita allocated to energy construction investments among the surveyed communes in a given year.

(b) Energy transport investments $\left(I_{T I}\right)$ :

$$
I_{T I}=\frac{C_{T x}}{C_{T \max }} \times 10
$$

where $C_{T x}$ is the level of expenditure per capita allocated to energy transport investments in a commune in a given year and $C_{T \max }$ is the highest level of expenditure per capita allocated to energy transport investments among the analyzed communes in a given year.

(c) External funds for the implementation of the climate and energy policy $\left(M_{T}\right)$ :

$$
M_{T}=\frac{M_{X}}{M_{X \max }} \times 10
$$

where $M_{X}$ is the number of external funds spent per capita by the commune for the implementation of the climate and energy policy in a given year and $M_{X \max }$ is the highest level of external funds spent per capita by a commune on the implementation of the climate and energy policy among the analyzed communes in a given year.

(d) Social campaigns of the year $\left(S_{A}\right)$ :

$$
S_{A}=\frac{C_{S x}}{C_{S \max }} \times 10
$$

where $C_{S x}$ is the level of expenditure per capita allocated to social actions related to the implementation of the climate and energy policy in the commune in a given year and $C_{S \max }$ is the highest level of expenditure per capita allocated to social actions related to the implementation of the climate and energy policy among the surveyed communes in a given year.

Moreover, the presence of the climate and energy policy in strategic documents of the commune was also taken into account, with points awarded according to the following criteria:

- If there is a document dedicated to the climate and energy policy, 10 points;

- If the issues of the climate and energy policy are an element of another strategic document of the commune, 5 points;

- If there are no provisions of the climate and energy policy in the commune's strategic documents, 0 points.

The second part of measuring the energy innovativeness of local governments consisted in the subjective assessment of one model innovation implemented in a given year, indicated by the local government. The innovation was selected from among four areas:

- Energy construction investment;

- Energy transport investment;

- Innovative social action on the subject of climate and energy policy;

- Energy innovation in general meaning.

The assessment was carried out by a team of experts composed of eight representatives of the scientific and journalistic communities as well as the energy and local government 
sectors, who awarded points based on specific criteria, as presented in Tables 1-4. The choice of criteria was aimed at the multifaceted evaluation of the investment. Each criterion could be rated on a scale of 0 to 5 points. The maximum number of points for the subjective assessment of a model investment or social action could be 50 points.

(1) Energy construction investment:

Table 1. Criteria for assessing the innovativeness of a commune in the area of energy construction investment.

\begin{tabular}{cll}
\hline No. & Assessment Criterion & Score Range \\
\hline 1. & The social need for investment & $0-5$ points \\
2. & The functionality of the investment & $0-5$ points \\
3. & Investment impact area/investment scale & $0-5$ points \\
4. & The impact of investments on reducing energy consumption & $0-5$ points \\
5. & The scale of increasing the share of RES & $0-5$ points \\
6. & The impact of the investment on the environment; e.g., & $0-5$ points \\
7. & Involvement of external funds to finance investments & $0-5$ points \\
8. & Time of investment implementation & $0-5$ points \\
9. & An investment that fits into the implementation of strategic & $0-5$ points \\
10. & Eocuments: local, national, European & $0-5$ points \\
\hline
\end{tabular}
Source: Own study.

\section{(2) Energy transport investment:}

Table 2. Criteria for assessing the innovativeness of a commune in the area of energy transport investment.

\begin{tabular}{cll}
\hline No. & Assessment Criterion & Score Range \\
\hline 1. & The social need for investment & $0-5$ points \\
2. & The functionality of the investment & $0-5$ points \\
3. & Investment impact area/investment scale & $0-5$ points \\
4. & The impact of investments on reducing energy consumption & $0-5$ points \\
5. & Increasing public interest in using public transport & $0-5$ points \\
6. & The impact of the investment on the environment; e.g., & $0-5$ points \\
7. & Involvement of external funds to finance investments & $0-5$ points \\
8. & Time of investment implementation & $0-5$ points \\
9. & An investment that fits into the implementation of strategic & $0-5$ points \\
10. & Eocuments: local, national, European & $0-5$ points \\
\hline
\end{tabular}

Source: Own study.

(3) Innovative social action on the subject of climate and energy policy:

In the next step, the scores from the first and second parts of the assessment were summed up. The maximum number of points to be scored amounted to 100. On this basis, the level of innovativeness of the commune in the field of energy was determined according to the scale presented in Table 5. 
Table 3. Criteria for assessing the innovativeness of a commune in the area of innovative social action on climate and energy policy.

\begin{tabular}{|c|c|c|}
\hline No. & Assessment Criterion & Score Range \\
\hline 1. & The social need for action & $0-5$ points \\
\hline 2. & The size of the target group; the type of group & $0-5$ points \\
\hline 3. & $\begin{array}{l}\text { The area of influence of the social action: locally, regionally, } \\
\text { nationally, internationally }\end{array}$ & $0-5$ points \\
\hline 4. & The impact of investments on reducing energy consumption & $0-5$ points \\
\hline 5. & $\begin{array}{l}\text { The scale of involvement of local entrepreneurs in the social } \\
\text { campaign }\end{array}$ & $0-5$ points \\
\hline 6. & $\begin{array}{l}\text { The impact of the investment on the environment; e.g., } \\
\text { reduction in } \mathrm{CO}_{2} \text { emissions }\end{array}$ & $0-5$ points \\
\hline 7. & Involvement of external funds to finance a social campaign & $0-5$ points \\
\hline 8. & Innovation in social action & $0-5$ points \\
\hline 9. & $\begin{array}{l}\text { Social action in line with the implementation of the provisions } \\
\text { of strategic documents: local, national, European }\end{array}$ & $0-5$ points \\
\hline \multirow[t]{2}{*}{10.} & The economic effectiveness of social action & $0-5$ points \\
\hline & Maximally & $0-50$ points \\
\hline
\end{tabular}
Source: Own study.

(4) Energy innovation in general meaning:

Table 4. Criteria for evaluating the innovativeness of a commune in the area of energy innovation in general.

\begin{tabular}{cll}
\hline No. & Assessment Criterion & Score Range \\
\hline 1. & The social need for action & $0-5$ points \\
2. & Functionality of innovation & $0-5$ points \\
3. & The area of innovation impact/the scale of innovation & $0-5$ points \\
4. & Impact of innovation on reducing energy consumption & $0-5$ points \\
5. & The scale of increasing the share of RES & $0-5$ points \\
6. & The impact of innovation on the environment; e.g., reduction in & $0-5$ points \\
7. & Involvement of external funds to finance innovation & $0-5$ points \\
8. & Time of implementation of innovation & $0-5$ points \\
9. & Innovation in line with the implementation of strategic & $0-5$ points \\
10. & Economic efficiency of innovation & $0-5$ points \\
\hline
\end{tabular}

Table 5. Scale defining the level of innovativeness of a commune.

\begin{tabular}{ccc}
\hline Innovation Category & Innovation Level & Number of Points \\
\hline I & Highly innovative & $76-100$ points \\
II & Innovative & $51-75$ points \\
III & Moderately innovative & $31-50$ points \\
IV & Low innovative & $16-30$ points \\
V & Non-innovative & $0-15$ points \\
\hline
\end{tabular}

Source: Own study.

From all over Poland, 30 communes participated in the study. There were 14 urban communes, 8 rural communes, and 8 urban-rural communes (Table 6), located in 13 different voivodeships (out of the 16 existing in Poland). All the municipalities that entered the National Competition for the Most Energy Innovative Local Government were selected. As the invitation to the competition, and thus to the survey, was sent to all local governments in Poland, from among which 30 municipalities applied, it can be concluded that the selection of municipalities was random. As a part of the model innovations submit- 
ted for assessment, completed by 31 December 2020, there were 17 proposals for energy construction investment, 2 solutions in the field of energy transport investment, 8 tasks that were assigned as general energy innovation, and 3 social campaigns to promote the idea of climate and energy policy. The study was conducted in the period from April to July 2021. As mentioned, the study was conducted within the framework of the First National Competition for the Most Energy Innovative Local Government, organized by the Institute of Energy Policy of the name of Ignacy Łukasiewicz based in Jasionka near Rzeszów (Poland), in cooperation with the Rzeszów University of Technology of the name of Ignacy Łukasiewicz (Poland). The aim of the competition was convergent with the aim of the research, and it was to increase the awareness of the society and local authorities about the importance of energy in environmental protection. The task of this competition was also to encourage the inhabitants of communes to play the role of active and conscious users and to activate local governments to actions to accelerate the modernization of the Polish energy sector and improve air quality [52].

Table 6. Communes covered by the research, together with the assessed area of innovation.

\begin{tabular}{|c|c|c|c|c|}
\hline No. & Community & Province & Type of Commune & The Area of Innovation \\
\hline 1. & Besko & Podkarpackie & Rural & Energy innovation \\
\hline 2. & Busko-Zdrój & Świętokrzyskie & Urban-rural & Energy construction investment \\
\hline 3. & Dzierzgoń & Pomorskie & Urban-rural & Energy innovation \\
\hline 4. & Dzierżoniów & Dolnośląskie & Urban & Energy innovation \\
\hline 5. & Ełk & Warmińsko-mazurski & Urban & Energy construction investment \\
\hline 6. & Gdynia & Pomorskie & Urban & Social action \\
\hline 7. & Głogówek & Opolskie & Urban-rural & Energy transport investment \\
\hline 8. & Grudziądz & Kujawsko-pomorskie & Urban & Energy construction investment \\
\hline 9. & Jarocin & Wielkopolskie & Urban-rural & Energy innovation \\
\hline 10. & Katowice & Śląskie & Urban & Social action \\
\hline 11. & Krzeszowice & Małopolskie & Urban-rural & Energy construction investment \\
\hline 12. & Kuźnia Raciborska & Śląskie & Urban-rural & Energy construction investment \\
\hline 13. & Lubartów & Lubelskie & Urban & Social action \\
\hline 14. & Łęczyca & Łódzkie & Rural & Energy innovation \\
\hline 15. & Masłów & Świętokrzyskie & Rural & Energy construction investment \\
\hline 16. & Mielec-miasto & Podkarpackie & Urban & Energy construction investment \\
\hline 17. & Pabianice & Łódzkie & Urban & Energy construction investment \\
\hline 18. & Potęgowo & Pomorskie & Rural & Energy construction investment \\
\hline 19. & Przechlewo & Pomorskie & Rural & Energy innovation \\
\hline 20. & Przywidz & Pomorskie & Rural & Energy innovation \\
\hline 21. & Rawa Mazowiecka & Łódzkie & Urban & Energy transport investment \\
\hline 22. & Rzeszów & Podkarpackie & Urban & Energy innovation \\
\hline 23. & Siemianowice Śląskie & Śląskie & Urban & Energy construction investment \\
\hline 24. & Słupsk Gmina & Pomorskie & Rural & Energy construction investment \\
\hline 25. & Sopot & Pomorskie & Urban & Energy construction investment \\
\hline 26. & Sulejów & Łódzkie & Urban-rural & Energy construction investment \\
\hline 27. & Tychy & Śląskie & Urban & Energy construction investment \\
\hline 28. & Wałcz & Zachodniopomorskie & Urban & Energy construction investment \\
\hline 29. & Wojaszówka & Podkarpackie & Rural & Energy construction investment \\
\hline 30. & Źukowo & Pomorskie & Urban-rural & Energy construction investment \\
\hline
\end{tabular}

Source: Own study.

Before starting empirical research based on the collected material, a theoretical analysis of the topic was carried out based on the literature on the subject. The concepts of innovation and innovativeness were defined, with a particular focus on innovation in local governments, as well as in the energy sector. A review of energy innovation leaders among local governments in the world had been made. While analyzing the obtained responses, methods of data processing and interpretation were used in the form of comparative analysis. The descriptive, tabular, and graphic methods were used to present the research results. This was followed by qualitative research in the form of a case study in which three 
model innovations, one for each area, were presented. It was aimed at understanding the uniqueness of the indicated problem, as well as indicating its context and interaction with other elements. The use of the case study method makes it possible to verify the results of the quantitative study, as well as to test the methodology used in the assessment of energy innovation in communes.

The source of data on the amount of financial expenditure on individual areas of innovation, model innovation, and the presence of climate and energy policy provisions in strategic documents was the information provided by local governments on specially prepared forms. The case study was supplemented with materials from municipal offices available on local websites.

\section{Energy Innovations in Polish Cities and Communes}

\subsection{Financial Outlays of Local Governments for Energy Innovations}

The research on energy innovation in Polish municipalities carried out in 2021 concerned activities carried out by local governments in 2020 . Using the developed methodology, in the first stage, the level of innovation of local governments was assessed based on financial expenses for activities in three areas: energy construction investment, energy transport investment, and energy social campaign. Due to the diversity of local governments in terms of population, area, and type (urban, rural, or urban-rural), the level of financial expenditure per 1 resident of the commune was adopted for the assessment.

In the first case, the level of innovation of local governments was assessed in terms of energy construction investments. This area includes financing of investments improving the energy efficiency of buildings, reduction of energy consumption for heating and domestic water heating in municipal residential buildings, measures aimed at reducing air pollution, projects in the field of modernizing the local energy sector, investments in renewable energy sources, and the development of distributed energy.

The conducted research shows that local governments invested on average about PLN 304.84 per capita in activities related to energy construction (Figure 1). The highest costs in this area were incurred by rural communes, where on average around PLN 775 per person was spent. Significantly fewer amounts per capita were spent in urban communes (PLN 141.62) and the least in urban-rural communes (PLN 120.11). Such a big difference in expenditure per capita was mainly related to the lower number of inhabitants in rural communes. There were mainly strategic investments, for which high subsidies were obtained from external funds, especially from EU funds. For example, the value of the project described in the case study entitled "Eco Energy from Somonina to Przywidz" (PL: "Eko Energia od Somonina aż po Przywidz") in the Przywidz commune concerning the construction of a photovoltaic micro-installation was approximately PLN 10 million and the number of inhabitants in this commune was 5,752. Another example was the investment in the rural commune of Besko in the Podkarpackie Voivodeship, where the construction of a multifunctional system limiting the energy needs of the sewage treatment plant with accompanying facilities was implemented. Additionally, in this commune, the construction of photovoltaic installations on public utility buildings was carried out and the construction of facilities in a passive system was performed. The total cost of these activities in 2020 was over PLN 2.2 million, which per person, with a population of 4,508, amounted to PLN 508.15.

In larger self-government units, especially in cities where the value of projects was much higher, the value of expenditure per person was lower due to a much larger number of inhabitants. An example is Gdynia, where construction investments in the field of energy implemented in 2020 reached a value of over PLN 30 million. Calculated per capita, it was only PLN 125.23.

The energy construction investments, regardless of the type and size of the commune, were similar. Investments in renewable energy sources prevailed, including investments in photovoltaic installations, wind farms, biogas plants, and heat pumps, as well as in new heating network installations and thermal modernization of public utility facilities. The 
effect of these investments was a significant reduction in final energy consumption, as well as a decrease in greenhouse gas emissions and savings in heating energy bills.

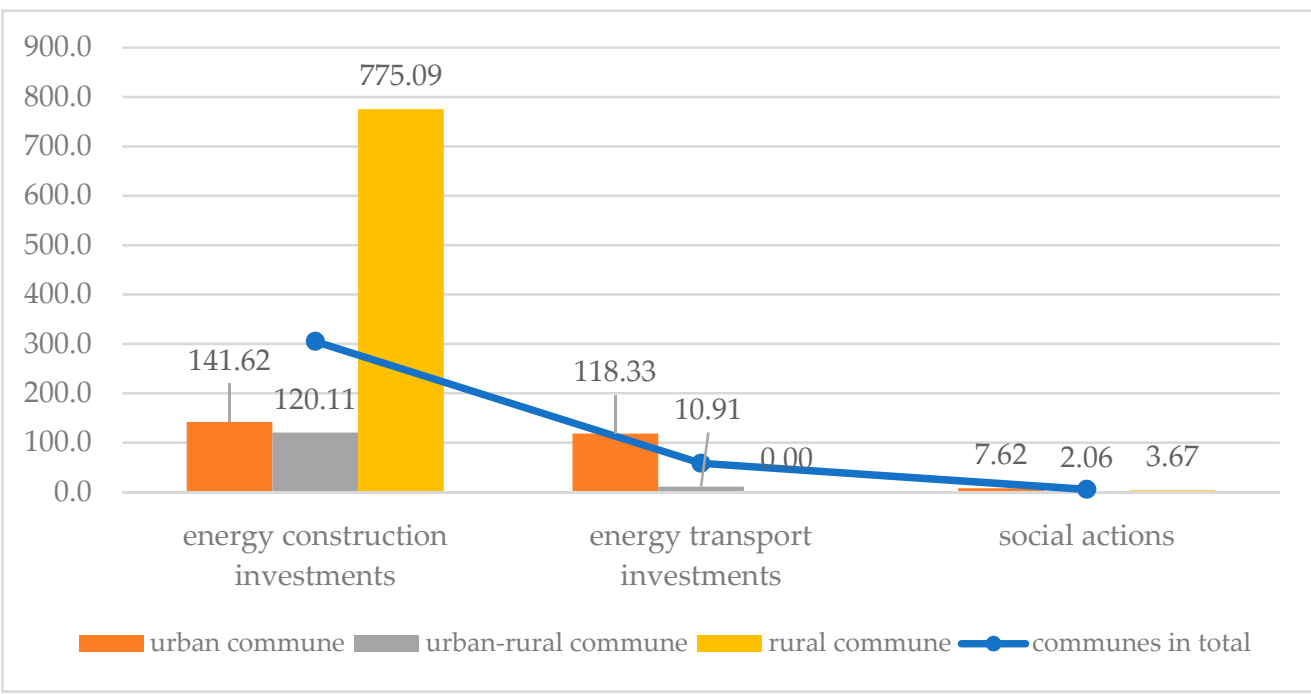

Figure 1. The average expenditure of communes on energy innovations within individual areas per capita in 2020. Source: Own study.

A decidedly different situation occurred in the case of energy innovations in transport. Rural municipalities invested the most financial resources. In cities, an average of PLN 118.33 per capita was spent in 2020 on the purchase of low and zero-emission transport, the implementation of innovative transport traffic management systems, the development of public transport and vehicle sharing systems, and the development of energy-efficient and low-emission transport. Lower financial expenses in this area were incurred in urban-rural communes (PLN 10.91 per person), mainly for the construction of bicycle road infrastructure or the expansion of parking lots at railway stops in the park-and-ride system. In the analyzed rural communes, no investments in this area were carried out. As many as $63 \%$ of the surveyed municipalities did not incur costs for energy innovations in transport. It was related to the fact that rural communes do not have their own transport companies and as the organizer of public transport, they outsource transport to private entities or neighboring city municipalities. Moreover, there is still low availability of cycling infrastructure in rural areas.

Another area of research was expenditure on social campaigns conducted by local governments that contribute to raising public knowledge and awareness in the field of energy efficiency. Such activities are, in particular, to stimulate the activity of the inhabitants of municipalities as energy consumers, increase their awareness of climate change and ways to minimize its effects and the principles of operation of energy and gas fuel markets, shape pro-ecological attitudes among local communities, and encourage local entrepreneurs to become more active in climate and energy policy measures. The research shows that the expenditure of the surveyed local governments on social campaigns was small. On average, only PLN 5.21 was spent per capita. This situation was caused mainly by the development of the SARS-CoV2 coronavirus pandemic and related mobility restrictions, bans on organizing mass events and smaller gatherings, as well as distance education. The highest expenses were incurred in city municipalities, on average PLN 7.62 per capita. In rural communes, the amount of these expenses was PLN 2.06 per capita. In rural communes, less than half the funds was spent on social actions than in urban communes, and in urban-rural communes, it was three times less than that in urban ones. Such a difference in expenditure between particular types of communes could have been caused by the pandemic and a greater distance to sanitary restrictions introduced by residents of smaller towns. Among the activities aimed at raising the awareness of residents about the 
climate and energy policy, one can mention the organization of the Olympics, a knowledge competition in the field of energy efficiency and environmental protection in Gdynia, or the educational and information campaign "\#nie Truj" on smog and air quality in the city conducted in Katowice.

In the next stage of the research, the distribution of expenditure in communes into individual areas of innovation was analyzed taking into account the type of local government unit. As shown by the data (Figure 2), the smallest differences in expenditure on innovation occurred in city municipalities. In the case of construction investments, most cities incurred financial expenses ranging from PLN 25 to PLN 200 per capita. Higher expenditures occurred only in the commune of Sopot, where they amounted to PLN 427.85 per capita, and in Grudziądz-PLN 497.85 per capita. Smaller discrepancies in the expenditure of municipal communes were recorded in the case of energy investments in transport. In 2020, cities spent on this purpose from about PLN 20 per inhabitant in Krzeszowice to approximately PLN 230 per inhabitant in Wałcz. In the case of three cities, these expenses were higher and ranged from PLN 282.17 per inhabitant in Gdynia to PLN 426.49 per inhabitant in Tychy.

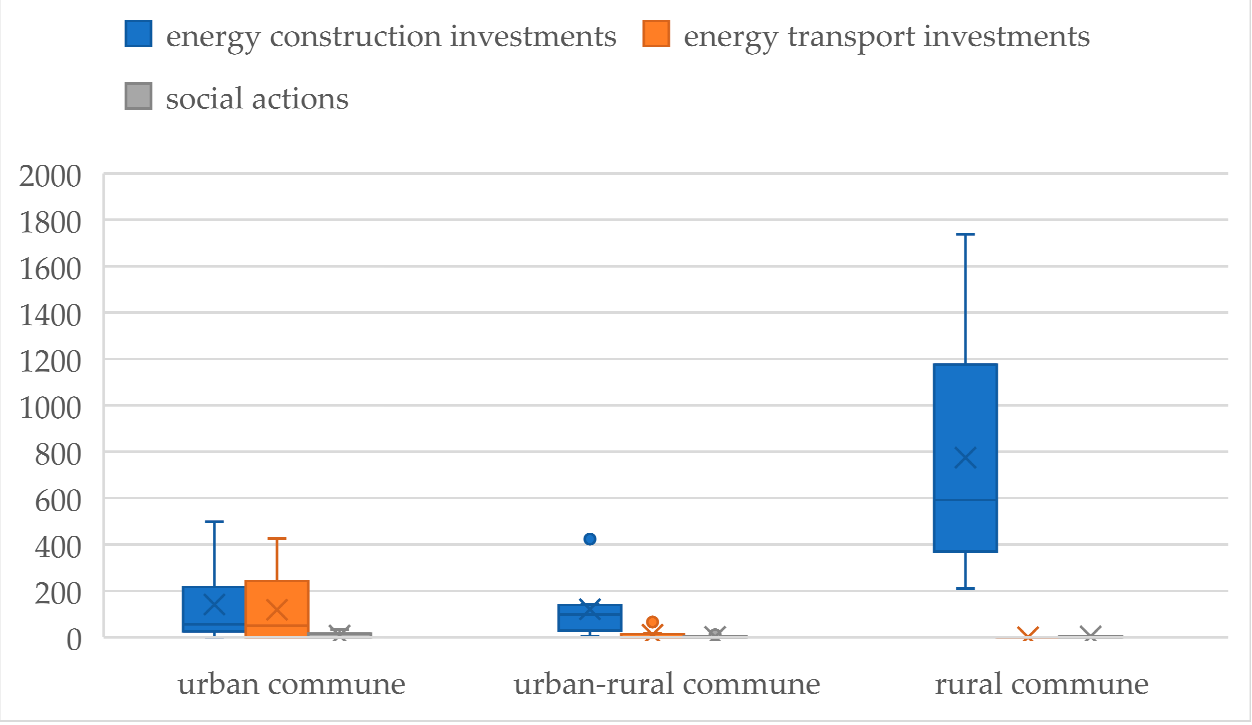

Figure 2. Distribution of municipalities' expenditure on energy innovations within individual areas and social campaigns per capita in 2020. Source: Own study.

Much greater discrepancies in expenditure occurred in the case of rural communes. The amount of expenditure on construction investments varied there from approximately PLN 400/inhabitant in the Sulejów commune to approximately PLN 1200 per inhabitant in the Potegowo commune. However, in the commune of Przywidz, as much as PLN 1738.53 per person was allocated to innovations in the field of construction investments.

As a part of the expenditure on the organization of social campaigns, the most funds were spent in the Lubartów commune-PLN 32.91 per capita. In most communes, less than PLN 1 per person was allocated for this purpose.

The implementation of the climate and energy policy requires many financial outlays, which was confirmed by the analyses performed. Each local government has a wide range of its own tasks, which largely involve the local budget. In this situation, municipal authorities successively obtain financial support from external sources for the implementation of various projects. In general, these are national or EU support funds. As part of national programs, one can list those implemented through the National Fund for Environmental Protection and Water Management or with the participation of government projects supporting the climate and energy policy. However, the most popular form of support are operational programs, through which local governments receive large funds from the European Cohesion Fund or the European Regional Development Fund. In the surveyed group 
of local governments, $80 \%$ of investments and innovations obtained support from external funds, on average at the level of PLN 237.69 per capita (Figure 3). The biggest amount of external funds for investments was spent by rural self-governments, on average PLN 529.51 per capita. The leader in this respect was the Przywidz commune, which allocated as much as PLN 1738.53 per capita for energy innovations. It is worth underlining that the co-financing concerned all innovative activities and the commune invested its funds only to cover its own contribution to implemented projects. In the case of other communes, the involvement of external funds for the implementation of energy innovations ranged from about PLN 100 to about PLN 600 per inhabitant.

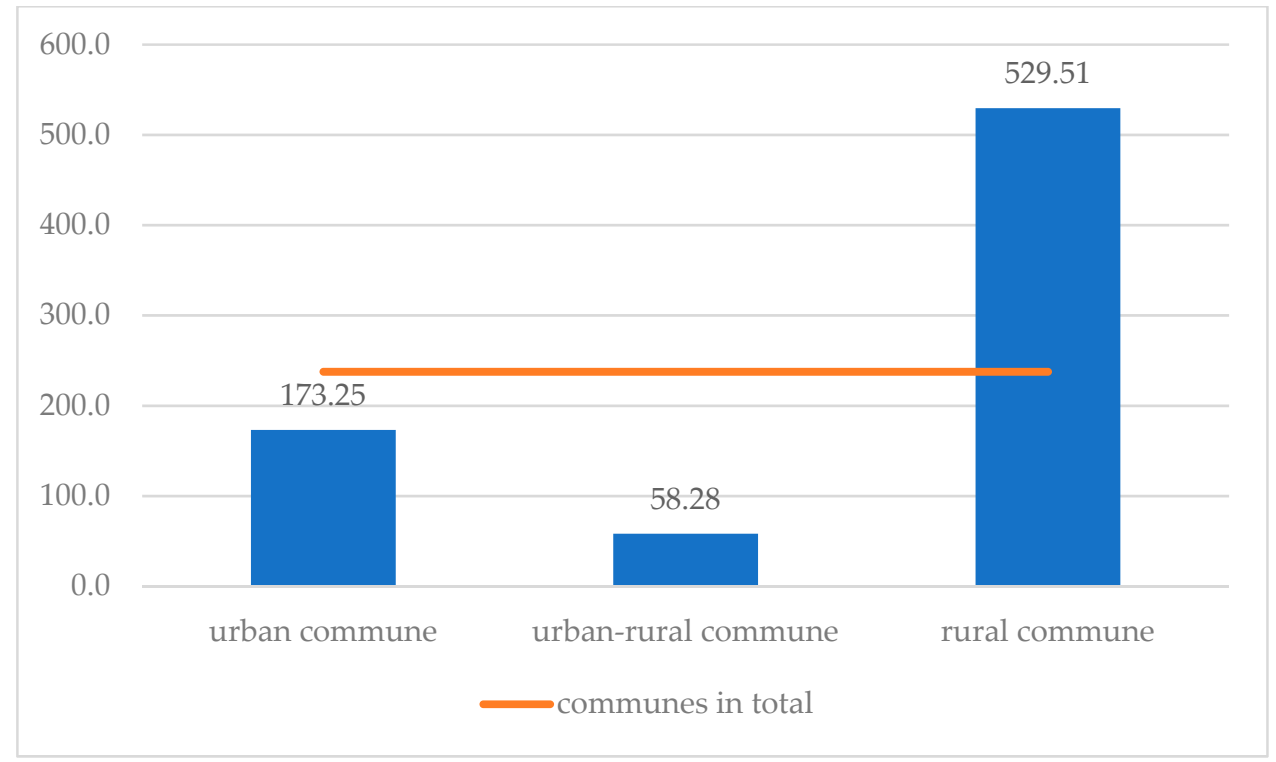

Figure 3. Municipalities' expenditure on innovations from external funds per capita in 2020. Source: Own study.

\subsection{Energy Innovation of Communes according to the Point Methodology}

The presence of the provisions of the climate and energy policy in local strategic documents played a significant role when assessing the innovativeness of communes. The number of documents developed by local governments that contribute to the creation of activities for the energy transformation is presented in Figure 4. The largest number of strategic documents dedicated only to the climate and energy policy was found in city municipalities (85.7\%). In other city self-governments, energy measures have been included as additional priorities in general local development strategies. In the case of rural communes, over $60 \%$ of the communes adopted strategic plans for actions for sustainable energy policy, and, in other local governments, the issues of climate and energy policy were part of another strategic document. In urban-rural communes, every tenth local government did not include any actions related to the energy transformation in the strategy and only in half of the communes, a separate document on climate and energy policy was developed.

The strategic documents presented by local governments where the entire plan is devoted to the issues of energy transformation include Low-Emission Economy Plan (Przywidz, Wojaszówka, Dzierzgoń, Pabianice, Pabianice, Rawa Mazowiecka, Grudziądz, and Głogówek); City Adaptation Plan to Climate Change until the 2030 Year (Rzeszów, Gdynia, Sopot, Katowice, and Siemianowice Ślaskie); Commune Environment Protection Program (Rzeszów and Głogówek); Electromobility Development Strategy for the BuskoZdrój Commune for 2019-2039; Plan for the Supply of Heat, Electricity, and Gaseous Fuels (Grudziądz); and Activities of the City of Ełk to Reduce $\mathrm{CO}_{2}$ Emissions by 2020. 


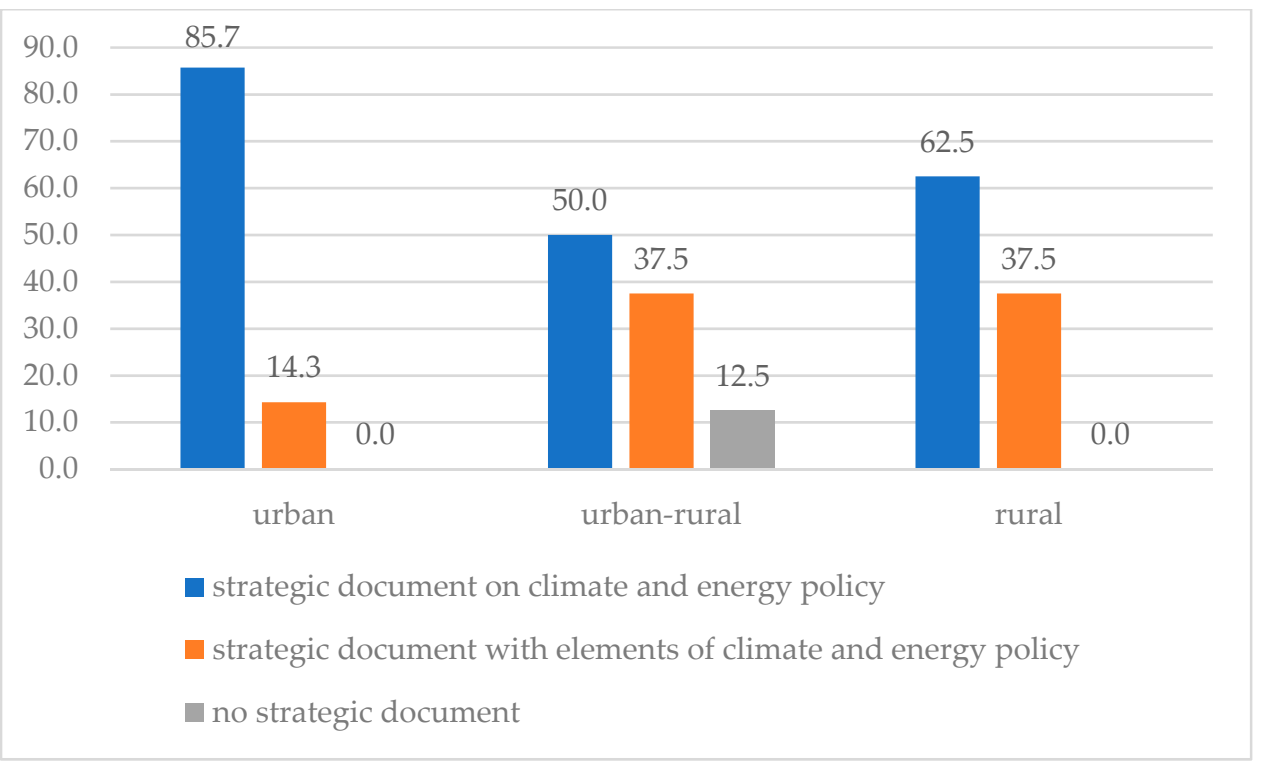

Figure 4. Communal strategic documents in the field of climate and energy policy (\%). Source: Own study.

The methodology used to assess the level of innovativeness of municipalities consists in adding up points:

- For expenditure incurred by local governments on measures for energy innovation in various areas;

- For having a strategic document containing provisions for the implementation of tasks in the field of energy transformation;

- Awarded by experts based on the innovation assessment of model projects under the implementation of the climate and energy policy.

In the case of expenditure on innovative activities, the commune of Przywidz was the undisputed leader; it was awarded 27.60 points of the 40.00 points possible, mainly for the highest level of expenditure on energy innovations for constructions and a large share of external funds. Next was the commune of Gdynia, which scored 15.96 points. Out of the remaining communes, only three local governments received more than 10.00 points in this evaluation category.

In the assessment of model innovations in various areas indicated by local governments, independent experts could award a total of 50.00 points. According to the data, only $20 \%$ of the communes received more than 40.01 points. The highest-ranked local governments are the city of Rzeszów and Sopot, which were awarded ex aequo 43.00 points each. Over $23 \%$ of the surveyed communes received less than 30.00 points for exemplary innovations. The remaining communes were assessed in the range from 30.01 to 40.00 points.

The sum of partial points for financial outlays, model innovations, and the presence of provisions of measures for the implementation of the climate and energy policy in the strategic documents of communes allowed for a comprehensive assessment of the energy innovativeness of Polish communes. The highest number of points, 72.35 , was obtained by the Przywidz commune, and 12 other communes obtained more than 50.00 points, which allowed them to qualify for the second innovation category (Table 7). The obtained results indicate that over $43 \%$ of the surveyed communes in Poland are innovative in terms of implementing the climate and energy policy. 
Table 7. The level of energy innovation in communes in 2020.

\begin{tabular}{|c|c|c|c|c|c|}
\hline Commune & Province & ype of Commune & Area of Innovation & Final Grade & $\begin{array}{l}\text { Category and Level } \\
\text { of Innovation }\end{array}$ \\
\hline Przywidz & Pomorskie & Rural & Energy innovation & 72.35 & II-innovative \\
\hline Potęgowo & Pomorskie & Rural & $\begin{array}{c}\text { Energy construction } \\
\text { investment }\end{array}$ & 62.68 & II-innovative \\
\hline Sopot & Pomorskie & Urban & $\begin{array}{l}\text { Energy construction } \\
\text { investment }\end{array}$ & 62.17 & II-innovative \\
\hline Gdynia & Pomorskie & Urban & Social action & 60.83 & II-innovative \\
\hline Lubartów & Lubelskie & Urban & Social action & 59.90 & II-innovative \\
\hline Rzeszów & Podkarpackie & Urban & Energy innovation & 58.49 & II-innovative \\
\hline Łęczyca & Łódzkie & Rural & Energy innovation & 56.53 & II-innovative \\
\hline $\begin{array}{l}\text { Siemianowice } \\
\text { Śląskie }\end{array}$ & Śląskie & Urban & $\begin{array}{l}\text { Energy construction } \\
\text { investment }\end{array}$ & 56.23 & II-innovative \\
\hline Pabianice & Łódzkie & Urban & $\begin{array}{l}\text { Energy construction } \\
\text { investment }\end{array}$ & 54.82 & II-innovative \\
\hline Wojaszówka & Podkarpackie & Rural & $\begin{array}{l}\text { Energy construction } \\
\text { investment }\end{array}$ & 54.74 & II-innovative \\
\hline Besko & Podkarpackie & Rural & Energy innovation & 54.32 & II-innovative \\
\hline Sulejów & Łódzkie & Urban-rural & $\begin{array}{l}\text { Energy construction } \\
\text { investment }\end{array}$ & 52.41 & II -innovative \\
\hline Grudziądz & $\begin{array}{l}\text { Kujawsko- } \\
\text { pomorskie }\end{array}$ & Urban & $\begin{array}{l}\text { Energy construction } \\
\text { investment }\end{array}$ & 52.40 & II-innovative \\
\hline Katowice & Śląskie & Urban & Social action & 50.76 & $\begin{array}{l}\text { III-moderately } \\
\text { innovative }\end{array}$ \\
\hline Ełk & Innovative & Urban & $\begin{array}{l}\text { Energy construction } \\
\text { investment }\end{array}$ & 48.56 & $\begin{array}{l}\text { III-moderately } \\
\text { innovative }\end{array}$ \\
\hline Tychy & $\begin{array}{l}\text { Warmińsko- } \\
\text { mazurski }\end{array}$ & Urban & $\begin{array}{l}\text { Energy construction } \\
\text { investment }\end{array}$ & 48.50 & $\begin{array}{l}\text { III-moderately } \\
\text { innovative }\end{array}$ \\
\hline Jarocin & Śląskie & Urban-rural & Energy innovation & 47.40 & $\begin{array}{l}\text { III-moderately } \\
\text { innovative }\end{array}$ \\
\hline Masłów & Wielkopolskie & Rural & $\begin{array}{l}\text { Energy construction } \\
\text { investment }\end{array}$ & 47.09 & $\begin{array}{l}\text { III-moderately } \\
\text { innovative }\end{array}$ \\
\hline $\begin{array}{l}\text { Mielec- } \\
\text { miasto }\end{array}$ & Świętokrzyskie & Urban & $\begin{array}{l}\text { Energy construction } \\
\text { investment }\end{array}$ & 45.91 & $\begin{array}{l}\text { III-moderately } \\
\text { innovative }\end{array}$ \\
\hline Dzierzgoń & Podkarpackie & Urban-rural & Energy innovation & 45.15 & $\begin{array}{l}\text { III-moderately } \\
\text { innovative }\end{array}$ \\
\hline Krzeszowice & Pomorskie & Urban-rural & $\begin{array}{l}\text { Energy construction } \\
\text { investment }\end{array}$ & 44.25 & $\begin{array}{l}\text { III-moderately } \\
\text { innovative }\end{array}$ \\
\hline $\begin{array}{l}\text { Słupsk } \\
\text { Gmina }\end{array}$ & Małopolskie & Rural & $\begin{array}{l}\text { Energy construction } \\
\text { investment }\end{array}$ & 42.81 & $\begin{array}{l}\text { III-moderately } \\
\text { innovative }\end{array}$ \\
\hline Żukowo & Pomorskie & Urban-rural & $\begin{array}{l}\text { Energy construction } \\
\text { investment }\end{array}$ & 41.49 & $\begin{array}{l}\text { III-moderately } \\
\text { innovative }\end{array}$ \\
\hline Wałcz & Pomorskie & Urban & $\begin{array}{l}\text { Energy construction } \\
\text { investment }\end{array}$ & 40.92 & $\begin{array}{l}\text { III-moderately } \\
\text { innovative }\end{array}$ \\
\hline Dzierżoniów & Zachodniopomorskie & Urban & Energy innovation & 40.07 & $\begin{array}{l}\text { III-moderately } \\
\text { innovative }\end{array}$ \\
\hline Głogówek & Dolnośląskie & Urban-rural & Energy transport investment & 38.69 & $\begin{array}{l}\text { III-moderately } \\
\text { innovative }\end{array}$ \\
\hline $\begin{array}{c}\text { Rawa } \\
\text { Mazowiecka }\end{array}$ & Opolskie & Urban & Energy transport investment & 37.18 & $\begin{array}{l}\text { III-moderately } \\
\text { innovative }\end{array}$ \\
\hline Przechlewo & Łódzkie & Rural & Energy innovation & 31.69 & $\begin{array}{l}\text { III-moderately } \\
\text { innovative }\end{array}$ \\
\hline Busko-Zdrój & Pomorskie & Urban-rural & $\begin{array}{l}\text { Energy construction } \\
\text { investment }\end{array}$ & 31.04 & $\begin{array}{l}\text { III-moderately } \\
\text { innovative }\end{array}$ \\
\hline $\begin{array}{c}\text { Kuźnia } \\
\text { Raciborska }\end{array}$ & Świętokrzyskie & Urban-rural & $\begin{array}{l}\text { Energy construction } \\
\text { investment }\end{array}$ & 28.32 & IV-low innovative \\
\hline
\end{tabular}


Category III of innovation was awarded to $53 \%$ of the surveyed communes. Therefore, they were classified as moderately innovative in the area of energy transformation. Only one commune, Kuźnia Raciborska, received less than 30.00 points, which meant that it was assessed as low energy innovative. The rather low score for this commune resulted from low financing of innovative activities. Unfortunately, no commune has been classified as highly innovative in the field of energy and thus received category I.

In terms of model innovations indicated by local governments, over $50 \%$ of the communes were classified in the second innovativeness category. They presented modern solutions in the field of energy-building innovations. In this category, there were also two local governments that presented social campaigns. The communes that indicated model innovations in the field of transport were assessed at an average level, which contributed to classifying these communes at the moderately innovative level.

The conducted research on the level of energy innovation in Polish municipalities, in accordance with the developed point method, has shown that the analyzed municipalities are moderately innovative in terms of climate and energy policy. The average number of points obtained by all the surveyed local governments was 48.92 points. The most innovative in terms of energy were rural communes, whose average number of points was 52.77. A slightly lower average number of points was obtained by urban communes (51.20 points), which means that both rural and urban communes can be considered innovative. However, the average number of points for urban-rural communes was lower and amounted to 41.09, which indicates that these local governments are moderately innovative in terms of energy.

\section{Case Study}

\subsection{Przywidz Commune-The Leader of a Local Government in Poland Innovative in Energy}

The Przywidz Commune is a rural commune located in the Pomeranian Province, Gdańsk County, and covers an area of $129.62 \mathrm{~km}^{2}$. The commune consists of 18 villages inhabited by 5997 inhabitants [53]. As a model energy innovation, the commune authorities presented a project implemented from 2020, together with the commune of Somonina, entitled "Eco-Energy from Somonina to Przywidz". As a part of the project in the Przywidz Commune, 10 micro-installations have been made in public utility facilities, including on the roofs of schools in Trzepowo and Pomlewo, Nowa Wieś Przywidzka, and Przywidz and on the buildings of the commune office, the health center, and the sewage treatment plant. At the same time, the sports hall has acquired a $40 \mathrm{~kW}$ installation, i.e., its power plant. Additionally, 253 micro-innovations have been established on the private properties of residents. In the first stage of the investment, 22 systems with power from 3.1 to $7.44 \mathrm{~kW}$ were installed and in the second stage, 69 systems with power from 2.48 to $7.44 \mathrm{~kW}$. All systems are connected to the power grid. It is possible to adjust each installation using a smartphone application. The application allows the user to accurately monitor electricity production. The installations are based on SolarEdge brand inverters and Sunergy USA WORKS LLC panels [54]. The project aimed to increase the use of energy from renewable sources in the region. Due to the implementation of the investment, the energy security of the commune has improved, the energy balance has improved, and the emission of harmful substances has decreased. The leader of the project was the commune of Somonino, and the total value of the project was PLN 9,986,419.90, of which co-financing from the European Regional Development Fund under the Operational Program of the Pomeranian Voivodeship for 2014-2020 amounted to PLN 7,650,069.12, or 76.85\% of eligible costs [55].

\subsection{Potegowo-The Leader of Energy Construction Innovation in Poland}

The Potegowo Commune is a rural commune located in the Pomeranian Province, in Słupsk County. It covers an area of $228.50 \mathrm{~km}^{2}$. The commune consists of 22 villages inhabited by 6821 people [56]. As a model energy innovation in the field of construction, the municipal authorities presented the project completed in 2020 entitled "Construction of a Heating Network with Heat Nodes in the Commune of Potegowo". The project was 
carried out under a public-private partnership with Nadmorskie Elektrownie Wiatrowe Darżyno Spółka $z$ o.o. The essence of the investment was the use of the heat released into the atmosphere that was generated during the production of electricity in a biogas power plant of $2.4 \mathrm{MW}$ power powered by organic mass. The existing boiler house in the commune was built using the old technology, and its excessive use could lead to failure. At the same time, its operation resulted in high heat losses and high $\mathrm{CO}_{2}$ emissions. Therefore, the implementation of the project was started, under which the equipment was installed necessary for heat removal from the biogas power plant (peak low-temperature heating boiler with a capacity of $700 \mathrm{~kW}$, fueled by biogas and a heat exchanger with a capacity of $2400 \mathrm{~kW}$ ). A $4359.85 \mathrm{~m}$ long pre-insulated heating network, with connections to buildings, with an anti-diffusion barrier in Logstor technology has been built. The created heating network is made of pre-insulated pipes with an anti-diffusion barrier, produced by a continuous axial method with a diameter of $42.4 \times 2.6 / 110$ to $219.1 \times 4.5 / 315 \mathrm{~mm}$. In addition, the network has been equipped with an impulse alarm system that supervises failure locators in the active system. As part of the project, 21 heat nodes have also been built: 6 in public utility buildings and 15 in residential blocks. During the heating season, the network is supplied with water at $90 / 65^{\circ} \mathrm{C}$, and outside it, the temperature is lowered to $70 / 30{ }^{\circ} \mathrm{C}$. The installation allows new users to be added in the future.

As a result of the implementation of the innovation, about 1000-1400 inhabitants are included in the heating system. However, the most significant effect of the investment has been the decommissioning of the old coal-fired boiler house, which was emitting up to 3000 tons of $\mathrm{CO}_{2}$ annually. As a result, annual reductions in greenhouse gas emissions up to 2543.93 tons of $\mathrm{CO}_{2}$ equivalent are estimated. For residents, heating charges have been reduced by approximately $20 \%$. The total value of the project was PLN 8,431,507.29, of which the part belonging to the Potegowo Commune was PLN 7,335,085.29, for which the local government obtained funding of PLN 8,910,920.20 from the European Regional Development Fund under the Operational Program of the Pomeranian Voivodeship for 2014-2020 [57].

\subsection{Rzeszów Commune-An Innovator in the Field of Transport}

The Rzeszów Commune is a city with powiat rights and the capital of the Podkarpackie Province. The city covers an area of $129.01 \mathrm{~km}^{2}$ and has 198,476 inhabitants [58]. The city authorities indicated investments in low-emission transport as a model innovation. As a part of the implementation of the indicated project entitled "Integration of Various Forms of Collective Public Transport in Rzeszów" was, inter alia, the purchase of 60 pieces of $12 \mathrm{~m}$ Autosan brand buses powered by CNG. Each of the purchased vehicles is equipped with an engine that meets the EURO 6 standards and is fully adapted to the transport of people with disabilities. In addition, the vehicles have a passenger information system in the form of direction boards, a voice information system, and passenger counting gates and are equipped with mobile ticket machines. As a part of the project, 27 modern bus shelters have also been installed, of which 8 are equipped with a PV system. The shelters are made using BIPV technology, i.e., photovoltaics integrated with the construction industry. Frameless photovoltaic modules are made using glass-glass technology, thanks to which the shelters are adapted to the dimensions of the stops, constituting their integral part. Thanks to the use of high-performance PV modules with a minimum efficiency of $22 \%$ and energy-saving LED diodes, it is possible to illuminate them all night, even where there is a problem with connecting to the power supply. Additionally, a technology in the form of heating glass has been used, which enables heating of the stops in winters, and the modular structure allows for the installation of air conditioning to cool the surroundings in summers [59]. The result of the project implementation is the infrastructure integration of the ecological forms of transport operating in the urban and suburban area; improvement in the mobility of people with disabilities or people with reduced mobility; and improvement in the energy efficiency of urban transport by investing in transport with alternative drive systems and reducing the negative impact of transport on the environment, including reduction in 
noise and vibration as well as greenhouse gas emissions, mainly $\mathrm{CO}_{2}$. All this has had a positive effect on the improvement of the quality of life in the city. The value of the entire integrated investment amounted to PLN 215,606,141.35, of which co-financing of PLN 154,415,243.70 was obtained from the European Regional Development Fund under the Operational Program Eastern Poland [60].

\subsection{Katowice Commune-Energy Innovator and Knowledge Promoter}

The Katowice Commune is a city with powiat rights and the capital of the Silesian Voivodeship. The city covers an area of $164.64 \mathrm{~km}^{2}$ and has 290,553 inhabitants [58]. As part of the innovation, the city authorities indicated a social campaign entitled "\#nie Truj" (Don't poison). It was a broad educational and information campaign about smog and air quality in the city of Katowice. The campaign directed to residents was aimed at increasing their awareness of air pollution, the reasons for its formation, the impact on the quality of life, the dangers of smog, and the possibility of counteracting this phenomenon. The innovative social action was composed of five stages. As a part of the first stage, a chimney sweep on the roof of the building presented the propagation of smoke and pollutants coming out of the chimney with the help of a fired smoke candle. In this way, the direct impact of air pollution on human health was illustrated.

The second stage of the project consisted in the implementation of educational films on the combustion process and the formation of smog, as well as activities being undertaken by the city of Katowice as a part of the education and information of residents on the ban on burning waste and proper care of boilers or detection of incidents of burning that is prohibited. As a part of the third stage, an educational installation was made and presented, symbolizing a model of the city of Katowice, divided into two parts by a transparent partition. The first half of the structure was connected to an individual heat source-an old generation stove that filled with smoke. In this way, the negative impact of using old furnaces was illustrated. The second part of the model presented a green city with clean and smog-free air.

The next stage concerned the analysis of the fallout of dust emitted by individual heat sources. A model device was used for this. The ADMS 5 mathematical model was used to calculate and determine the range of precipitation and dust dispersion. Based on the results, a map of dust fall from a residential house in the winter was obtained.

The last stage was the launch of a mobile information point, Smogobus, i.e., a bus running around the districts of Katowice. Inside it, residents can apply for funding to change the heating systems in their homes and talk about measures to reduce air pollution and for the efficient use of energy. Smogobus was visited by 545 people, of which 160 residents applied for funding for the replacement of heat sources. The result of the implemented social investment was reaching the majority of the city's inhabitants with information about the carried out pro-ecological activities. The implementation of the action was possible thanks to obtaining funding from the Provincial Fund for Environmental Protection and Water Management in Katowice [61].

\section{Discussion}

Local governments are playing an increasing role in the transition to fully renewable, intelligent, and decentralized energy systems. This is due to the fact that municipalities own their land and also play a large role in transport and land development planning and proximity to key stakeholders. Additionally, local government authorities have the tools and direct influence on their inhabitants to encourage them to act for energy transformation. It is at the local level that projects are implemented that are directly aimed at the society as well as the economic entities located in these areas [62]. In his analyses, Poppo drew attention to the need to participate in research and development works of state and local authorities. He also showed that market power in the form of constantly increasing energy prices has a large impact on the creation and implementation of energy innovations [50]. The conducted research shows that the presence of provisions of the climate and energy 
policy in local strategic documents is of significant importance in the development of energy innovations.

Innovative activity at the local level may depend on various factors. However, the more local governments implement novelties, the faster the energy transformation will be carried out nationwide. The most innovative energy self-governments are located in the Scandinavian countries. It is not without reason that the first three places in the Global Energy Innovation Index (GEII) Ranking of the Information Technology and Innovation Foundation (ITIF) from 2021 [6] are, respectively, Finland, Denmark, and Sweden. The fourth country from Scandinavia, Norway, takes the 11th place, advancing by as many as 12 places. It should be noted that Denmark ranks first for knowledge development and dissemination and Finland is a leader in entrepreneurial experimentation and market creation. In the examined group of local governments, energy construction investments, regardless of the type and size of the commune, were similar. In urban municipalities, more funds were allocated to transport investments while the share of investments in social actions aimed at encouraging local communities to become more active in the activities of climate and energy policy was small.

In Denmark, municipal energy and climate plans play a key role. They are the state's policy result that assumes complete independence from fossil fuels. It is at the local level where the planning and implementation of future energy systems must take place [46]. The Danish Energy Agency and the Local Government of Denmark (association of municipalities) stated that "municipal work with energy supply is of great importance to the government's goals realisation of a fossil-free society and increased and continuous security of supply" [63]. The analysis [46] shows that local governments have set themselves a goal to reduce energy demand and achieve electricity savings in buildings of $50 \%$ by 2030 and heat savings of $50 \%$ by 2050 . In the case of transport, it is planned to achieve fuel savings of $44 \%$ by 2050 . These assumptions are to be achieved by modernizing buildings, building new ones with low energy consumption, and using energy-saving devices. In terms of transport, local authorities focus on improved public transport, integrated urban planning, as well as the use of intelligent traffic systems. Similar innovations types are also present in Polish local governments, which confirm the conducted research.

An example of a Danish municipality is the municipality of Samsø, which aims to balance systemic planning and experimentation. At the stage of developing an integrated energy plan, the municipality applied an integrative systems approach using the leadership role of the local government, active public participation, and local ownership. The result of the cooperation was the creation of an offshore wind farm in Paludans Flak. Two wind turbines were external investments, and eight wind turbines were owned locally: one was owned by a wind cooperative, two were owned by farmers, and the remaining five were purchased by a municipal energy company. The municipality of Samsø has invested EUR 17 million in five 2.3 MW wind turbines [62]. In the surveyed communes in Poland, some local governments also undertake team investments involving local communities and entrepreneurs of the commune. Such an example is the project presented by the Lubartów Commune: "Agreement for the development of renewable energy based on individual photovoltaic installations in the city of Lubartów-an agreement of local government and business for individual photovoltaic installations". As a result of the planned implementation, installations generating energy from renewable sources are created, supplying public buildings and local business facilities.

Another example in Denmark is the financing scheme for the energy-efficient renovation of single-family houses in the municipality of Høje-Taastrup in the Greater Copenhagen area. The project subsidized energy efficiency initiatives in private homes (an area that is usually beyond the reach of local authorities). Moreover, the financing system only supported comprehensive renovations with significant energy savings [63]. In this case also, the Polish equivalent of the activity can be found, consisting in the construction of 10 micro-installations on public buildings and 253 micro-installations on the real estate of residents (solar installations, thermal modernization of buildings, and photovoltaic instal- 
lations). This project is implemented in the commune of Przywidz, the most innovative commune in Poland.

A prime example in Sweden is the No Mine Energy District (FED) project, in terms of which a local energy system on the campus of the Chalmers University of Technology in Gothenburg has been built. The system connects different facilities and can control energy consumption, e.g., by heating the building for several hours before it cools down, and can ensure efficient use of locally produced renewable energy in a given area. It avoids energyintensive peaks and limits fossil energy imports [64]. Based on the conducted research, it can be seen that similar innovations are also implemented in Poland. For example, in Rzeszów, a project has been implemented to increase the share of energy from renewable sources in the entire agglomeration. Similar innovations have been implemented in the Wałcz Commune, where individual gas stoves were removed from residential buildings, due to which the energy efficiency of buildings has improved.

In the Netherlands, which is in the seventh place in the Global Energy Innovation Index Ranking, rural self-governments focus on ecovillages. One of the goals of an ecovillage is activities for a sustainable society, including environmental protection. For example, in Brabant, the priority goal was to produce green energy and thus achieve autonomy in this area [65]. In other ecovillages, innovations are implemented in the field of, among others, energy-saving housing and energy production [66]. A similar example of an ecovillage can be found among the surveyed Polish local governments. In the Wojaszówka Commune and the partner commune of Baligród, a project has been implemented consisting in the installation of solar collectors, photovoltaic cells, heat pumps, and pellet boilers in households. As a result, the two rural communes generate their own green energy.

An interesting initiative is the transition cities, which aim to focus on transition to a society where people, resilience, and biodiversity are important. Among these goals, there are also activities related to energy, economy, and climate. As in many European local governments, in transition cities, projects related to the production of local energy from renewable sources and the economic use of energy are in the first place [67]. The example of a transitional city is also found in Poland. The city of Jarocin, participating in the study, has established an energy cluster whose goal is the energy self-sufficiency of the commune by building renewable energy installations and its own distribution network.

In the United States, individual local governments mainly invest in innovative methods of obtaining green energy, thanks to which some cities or regions buy or produce even more than $100 \%$ of the energy they need that comes from renewable sources. Among the top 30 local governments, the use of energy from wind predominates, followed by solar energy [10]. In Poland, most local governments focus on the use of the sun as a source of renewable energy. Wind or water is used for the production of green energy by private enterprises and state-owned companies.

Analyses show that Polish municipalities implement measures for energy transformation similar to those implemented by local governments around the world. Almost every example presented has its counterpart in a Polish city or a Polish village. It confirms the special role of local governments in creating and implementing modern solutions.

Local governments play a special role in creating and implementing modern solutions. Municipal authorities have effective tools for use in their pursuit of innovation in the area of energy, construction, and transport investments, as well as organizing social campaigns related to the energy transformation. Moreover, local and regional authorities, through an effective innovation policy defined as a part of the regional innovation strategy, play a role that connects and stimulates the operation of individual social subsystems (production and services, education and research, infrastructure, etc.) [68].

\section{Conclusions}

For many years, the European Union has been intensifying efforts to achieve climate neutrality and, above all, tasks have been undertaken to facilitate the provision of clean, affordable, and safe energy. The main proposed course of action is to accelerate the global 
transformation in the area of a low-emission economy through the implementation of innovative solutions. They counteract climate change and, consequently, lead to economic growth, welfare, and quality of life.

It is essential for energy transformation that innovations in the energy sector are implemented at the local government level through local authorities and in public-private partnerships. The case studies presented in the study are a good example in this area. Such activities should also occupy an important place in the strategies and plans for the development of communes. National and European examples show that innovative activities for the implementation of climate and energy policy should be carried out comprehensively and combine areas related to technical and social infrastructure, methods of obtaining energy, and activities for environmental protection. In urban areas and other urbanized zones, three areas of innovative activity of local governments have been designated to accelerate the efforts to improve the energy efficiency of Polish communes. These are activities aimed at the modernization of individual heat sources, the aim of which is to significantly improve air quality, popularize technological processes of simultaneous generation of electricity and heat in heat-and-power plants, as well as intensify activities aimed at reducing the energy consumption of buildings and implementing business models, leading to an increase in the energy efficiency of facilities. Innovative educational methods are also important, as they increase the awareness of the society and make the inhabitants accustomed to implementing pro-ecological attitudes.

The conducted research shows that $43 \%$ of the surveyed communes in Poland are innovative and $53 \%$ are moderately innovative. The remaining communes were categorized as low innovative. None of the communes was considered highly innovative, but none was non-innovative either. Detailed analyses have shown that Polish self-governments usually specialize in a given area of innovation. If the municipal authorities large amounts of funds on innovations in the field of energy construction, then less funds are invested in social actions. Similarly, if a commune allocates large amounts of funds to energy innovations in transport, then it invests less in construction innovations.

As far as investments in energy innovations are concerned, there is considerable variation between particular types of communes. Smaller communes, in particular rural ones, allocate much greater financial resources per capita than larger communes to the implementation of modern solutions in the field of climate and energy policy implementation. In the case of a smaller social group, it is associated with high unit investment costs; therefore, it is important to obtain funds from external sources. This is because small communes are not able to finance investments the value of which reaches $50 \%$ of the annual budget of the local government. The obtained funding allows the project to be implemented and the commune to be recognized as pro-environmental.

Municipal authorities plan their activities by developing strategic documents. This also applies to tasks in the area of implementing the climate and energy policy. In this case, city self-governments are in the lead, $85 \%$ of which have developed various strategies that are specifically dedicated to the implementation of energy transformation. In the case of the surveyed rural self-governments, approximately $62 \%$ of the communes have such documents. The percentage of urban-rural communes in this respect is even smaller, as only $50 \%$ of them have such strategies.

Summing up, it can be stated that Polish self-governments implement the assumptions of the European Green Deal in a good and moderate manner. They pursue a policy aimed at protecting the natural environment by reducing harmful emissions and obtaining energy from renewable sources. Despite the difficult situation related to the coronavirus pandemic, communes have not stopped social activities that contribute to shaping positive attitudes of the society. In the conducted research, the authorial scoring method for assessing the innovativeness of communes was used for the first time. Due to the importance of the research, it is advisable to continue using the method in research later to identify trends in the field of energy innovation in communes in different areas. 


\begin{abstract}
Author Contributions: Conceptualization, S.S. and E.J.S.; methodology, S.S.; validation, S.S. and E.J.S.; formal analysis, S.S. and E.J.S.; investigation, S.S. and E.J.S.; resources, S.S.; data curation, S.S. and E.J.S.; writing — original draft preparation, S.S.; writing—review and editing, S.S. and E.J.S.; visualization, S.S.; supervision, E.J.S.; project administration, S.S.; funding acquisition, S.S. All authors have read and agreed to the published version of the manuscript.
\end{abstract}

Funding: This research was funded by ML System S.A. and Polski Koncern Naftowy Orlen S.A. and Polska Spółka Gazownictwa as part of the project "National Competition for the Most Innovative Energy Local Government.

Institutional Review Board Statement: Not applicable.

Informed Consent Statement: Not applicable.

Data Availability Statement: The data presented in this study were provided by Polish local governments and are publicly available data on the websites of municipal offices as a part of access to public information.

Acknowledgments: The authors thank hab. Mariusz Ruszel, president of the Institute of Energy Policy, and Institute of Energy Policy named after Ignacy Łukasiewicz for providing the data for this study.

Conflicts of Interest: The authors declare no conflict of interest. The funders had no role in the design of the study; in the collection, analyses, or interpretation of data; in the writing of the manuscript; or in the decision to publish the results.

\title{
References
}

1. Intergovernmental Panel on Climate Change. Special Report. Global Warming of $1.5^{\circ}$ C. 2019 , p. 4. Available online: https: / / www.ipcc.ch/sr15/download/ (accessed on 3 December 2021).

2. Szczyt Klimatyczny COP26. Available online: https://www.consilium.europa.eu/pl/policies/climate-change/paris-agreement/ cop26/ (accessed on 3 December 2021).

3. Paryskie Proozumienie Klimatyczne. Available online: https://www.consilium.europa.eu/pl/policies/climate-change/parisagreement/ (accessed on 3 December 2021).

4. Gotowi na 55. Available online: https://www.consilium.europa.eu/pl/policies/green-deal/eu-plan-for-a-green-transition/ (accessed on 3 December 2021).

5. European Commission. Komunikat Komisji do Parlamentu Europejskiego, Rady Europejskiej, Rady, Komitetu EkonomicznoSpołecznego i Komitetu Regionów “Europejski Zielony Ład”, COM(2019) 640 Final. Available online: https: / / eur-lex.europa.eu/ legal-content/PL/TXT/?uri=CELEX\%3A52019DC0640 (accessed on 4 December 2021).

6. Information Technology and Innovation Foundation. The 2021 Global Energy Innovation Index: National Contributions to the Global Clean Energy Innovation System. 2021. Available online: https:/ itif.org/publications/2021/10/18/2021-global-energyinnovation-index-national-contributions-global-clean (accessed on 17 January 2022).

7. Cleantech Group. 2017 Global Cleantech Innovation Index: A Look at Where Entrepreneurial Clean Technology Companies Are Most Likely to Emerge from over the Next 10 Years-And Why. 2017. Available online: https://www.cleantech.com/2017 -global-cleantech-innovation-index-a-look-at-where-entrepreneurial-clean-technology-companies-are-most-likely-to-emergefrom-over-the-next-10-years-and-why/ (accessed on 17 January 2022).

8. Heinrich-Böll-Stiftung Unia Europejska. Cities: Testbeds for Energy Innovation. Available online: https://eu.boell.org/en/2018 /04/24/cities-testbeds-energy-innovation (accessed on 29 January 2022).

9. Kightlinger, D. Cities Get Innovative to Finance Sustainable Energy Projects. Available online: https://www.ge.com/power/ transform/article.transform.articles.2018.sep.cities-get-innovative-finance (accessed on 29 January 2022).

10. United States Environmental Protection Agency. Green Power Partnership Top 30 Local Government. 2021. Available online: https: / / www.epa.gov/greenpower/green-power-partnership-top-30-local-government (accessed on 17 January 2022).

11. Shaver, L.; Ratz, H. 4 Creative Ways Cities Are Transitioning to a Clean Energy Future. World Resources Institute. Available online: https:/ / www.wri.org/insights/4-creative-ways-cities-are-transitioning-clean-energy-future (accessed on 29 January 2022).

12. World Economics Forum. REN21's Renewables in Cities Global Status Report. Available online: https://www.ren21.net/reports/ cities-global-status-report/ (accessed on 29 January 2022).

13. WSPglobal. Top 10 Cities in Power Generation and Distribution. Available online: https://www.wsp.com/en-GL/insights/top10-cities-in-power-generation-and-distribution (accessed on 29 January 2022).

14. Begin, K. 8 Innovative Cities Using Technology to Reduce Energy Use. Biofriendly Planet. Available online: https: / / biofriendlyplanet.com/eco-awareness / energy/8-innovative-cities-using-technology-to-reduce-energy-use/ (accessed on 29 January 2022).

15. Collier, U.; Löfstedt, R.E. Think globally, act locally? Local climate change and energy policies in Sweden and the UK. Glob. Environ. Change 1997, 7, 25-40. [CrossRef] 
16. Ea Energy Analysis, Gaia Group, Nordic Energy Research. Tracking Nordic Clean Energy Progress. Available online: https: / / www.nordicenergy.org/publications/tracking-nordic-clean-energy-progress/ (accessed on 29 January 2022).

17. Anderson, M.; Ödlund, L.; Westling, H. The role of the Swedish municipalities in the transition towards sustainable energy systems. WEENTECH Proc. Energy 2019, 5, 124-135. [CrossRef]

18. OECD. Public Sector Innovation Scan of Denmark. 2021. Available online: https://oecd-opsi.org/wp-content/uploads/2021/0 3/Public-Sector-Innovation-Scan-of-Denmark.pdf (accessed on 29 January 2022).

19. Jensen, A.; Nielsen, H.Ø.; Nielsen, M.L. Climate Adaptation in Local Governance: Institutional Barriers in Danish Municipalities; Scientific Report from DCE—Danish Centre for Environment and Energy, No. 104; Aarhus University: Aarhus, Denmark, 2016. Available online: http:/ / dce2.au.dk/pub/SR104.pdf (accessed on 29 January 2022).

20. Hoppe, T.; Graf, A.; Warbroek, B.; Lammers, I.; Lepping, I. Local Governments Supporting Local Energy Initiatives: Lessons from the Best Practices of Saerbeck (Germany) and Lochem (The Netherlands). Sustainability 2015, 7, 1900-1931. [CrossRef]

21. Urząd Regulacji Energetyki. IV Konkurs na Najbardziej Efektywną Energetycznie Gminę w Polsce. 2012. Available online: https:/ / www.ure.gov.pl/pl/urzad/informacje-ogolne/edukacja-i-komunikacja/patronaty/wydarzenia-objete-patro/43 25,dok.html (accessed on 17 January 2022).

22. Polska Agencja Prasowa. Innowacyjny Samorząd. Regulamin. 2021. Available online: https://innowacyjnysamorzad.pap.pl/ regulamin/ (accessed on 17 January 2022).

23. Ministerstwo Klimatu I Środowiska. Nowy Ranking Gmin w Programie “Czyste Powietrze”-Liderzy i Maruderzy. 2021 Available online: https:/ / czystepowietrze.gov.pl/nowy-ranking-gmin-w-programie-czyste-powietrze-liderzy-i-maruderzy / (accessed on 17 January 2022).

24. Schumpeter, J.A. Teoria Rozwoju Gospodarczego; Wydawnictwo Naukowe PWN: Warsaw, Poland, $1960 ;$ p. 104.

25. Wojciechowski, M. Innowacje w samorządzie terytorialnym. In Innowacje 2015. Rozwój Społeczeństwa Informacyjnego w Nowej Perspektywie Finansowej; Nowak, P.A., Ed.; Urząd Marszałkowski Województwa Łódzkiego: Łódź, Poland, 2015; p. 119. Available online: http:/ /bcpw.bg.pw.edu.pl/Content/5963 (accessed on 4 December 2021).

26. Kaczmarek, B. Wspótczesne Wyzwania dla Zarzadzania Przedsiębiorstwami; Towarzystwo Naukowe Organizacji i Kierownictwa Dom Organizatora: Torun, Poland, 2013; p. 55.

27. Freeman, C. The Economics of Industrial Innowation; F. Pinter: London, UK, 1982; p. 7.

28. Jashapara, A. Zarzadzanie Wiedza; Wydawnictwo Naukowe PWN: Warsaw, Poland, 2006; p. 91.

29. OECD; Eurostat. Oslo Manual 2018: Guidelines for Collecting and Interpreting Innovation Data, 3rd ed.; The Measurement of Scientific and Technological Activities; OECD Publishing: Paris, France, 2018.

30. OECD; Eurostat. Oslo Manual 2018: Guidelines for Collecting, Reporting and Using Data on Innovation, 4th ed.; The Measurement of Scientific, Technological and Innovation Activities; OECD Publishing: Paris, France; Eurostat: Luxembourg, 2018.

31. Dabrowska, M. Ekoinnowacje; Polska Agencja Rozwoju Przemysłu: Warsaw, Poland, 2010; p. 8.

32. Chądzyński, J. Innowacje, Sieci i Środowisko Innowacyjne a Rozwój Terytorium. Zrozumieć Terytorium. Idea i Praktyka; Wydawnictwo Uniwersytetu Łódzkiego: Łódź, Poland, 2013; pp. 129-130. Available online: https://dspace.uni.lodz. $\mathrm{pl} /$ xmlui / bitstream/handle/11089/23379/129-\%20146Ch\%c4\%85dzy\%c5\%84ski\%20Jacek\%2c\%20Innowacje\%2c\%20sieci\%20 i $\% 20 \%$ c5\% $\%$ brodowisko $\% 20$ innowacyjne $\% 20$ a $\% 20$ rozw $\%$ c3\%b3j\%20terytorium.pdf?sequence=1\&isAllowed=y (accessed on 5 December 2021).

33. Marciniak, S. Innowacje i Rozwój Gospodarczy; Kolegium Nauk Społecznych i Administracji Politechniki Warszawskiej: Warsaw, Poland, 1998; p. 52.

34. Baruk, J.; Innowacje, Kultura Innowacyjna i Poziom Innowacyjności Przedsiębiorstw Przemysłowych. Gospodarka Narodowa 2002, No. 11-12. 2002, p. 80. Available online: http://yadda.icm.edu.pl/yadda/element/bwmeta1.element.ekon-element-0000 00115709 (accessed on 5 December 2021).

35. Łyżwa, E. Innowacyjność Przedsiębiorstw a Konkurencyjność Regionów; Wydawnictwo Uniwersytetu Jana Kochanowskiego: Kielce, Poland, 2014; p. 75.

36. Główny Urzą Statystyczny. Pojęcia Stosowane w Statystyce Publicznej. Available online: https://stat.gov.pl/metainformacje/ slownik-pojec/pojecia-stosowane-w-statystyce-publicznej/4253, pojecie.html (accessed on 7 December 2021).

37. Rumpel, P. Innowacyjne podejście do sterowania rozwojem miast. Studium przypadku miasta Vse-tin. In Polityka Zrównoważonego Rozwoju Oraz Instrumenty Zarzadzania Miastem; Słodczyk, J., Rajchel, D., Eds.; Wydawnictwo Uniwersytetu Opolskiego: Opole, Poland, 2006; p. 187.

38. Szromnik, A. Marketing Terytorialny; Wolters Kluwer Poland: Kraków, Poland, 2007; p. 203.

39. Ministry of Energy. eIN Innovations for Energy. Directions od Energy Innovation Development; Ministry of Energy: Warszaw, Poland, 2017; pp. 26-38. Available online: https://www.gov.pl/attachment/b5eacab6-67a7-4e0a-8f44-f924f3ebfbd4 (accessed on 7 December 2021).

40. Saint-Gobain. Polskie Miasta Przyszłości 2050. 2021, pp. 14-22. Available online: www.miastaprzyszlosci2050.pl (accessed on 7 December 2021). 
41. International Renewable Energy Agency. Innovation Priorities to Transform the Energy System-An Overview for Policy Makers; International Renewable Energy Agency: Abu Dhabi, United Arab Emirates, 2018; p. 23. Available online: https: //www.irena.org/-/media/Files/IRENA/Agency/Publication/2018/May/IRENA_Innovation_priorities_2018.pdf (accessed on 7 December 2021).

42. Central Europe Energy Partners. Energy Innovations in Central Europe. Developments, Challenges and the Way Forward; Central Europe Energy Partners: Brussels, Belgium, 2017; pp. 2-3. Available online: https://www.ceep.be/www/wp-content/uploads/ 2017/12/CEEP-policy-paper-CEDE2017.pdf (accessed on 7 December 2021).

43. Okraszewska, E. Znaczenie i uwarunkowania innowacji w sektorze energetycznym. In Wspótczesne Problemy Ekonomiczne w Badaniach Młodych Naukowców. Vol. 2, Zarzadzanie Organizacja, Finanse i Inwestycje; Gruszewska, E., Matel, A., KuzionkoOchrymiuk, E., Eds.; Polskie Towarzystwo Ekonomiczne: Białystok, Poland, 2018; pp. 49-52.

44. Zawada, M.; Pabian, A.; Felicjan, B.; Chichobłaziński, L. Innowacje w sektorze energetycznym. In Zeszyty Naukowe Politechniki Częstochowskiej. Zarządzanie Nr 19; Politechnika Częstochowska: Częstochowoa, Poland, 2015; pp. 8-17.

45. Planeta, B.; Sobótka, K. Magazynowanie Lub Komplementarne Wykorzystanie Energii Wiatrowych. Available online: https://www.energetykacieplna.pl/artykuly/magazynowanie-lub-komplementarne-wykorzystywanie-energii-elektrowniwiatrowych-37064-6 (accessed on 18 January 2022).

46. Sperling, K.; Arler, F. Local government innovation in the energy sector: A study of key actors' strategies and arguments. Renew. Sustain. Energy Rev. 2021, 126, 109837. [CrossRef]

47. Poggi, F.; Firmino, A.; Amado, M. Shaping energy transition at municipal scale: A net-zero energy scenario-based approach. Land Use Policy. 2020, 99, 104955. [CrossRef]

48. Research Institutes of Sweden. RISEnergy: Roadmaps for Energy Innovation in Sweden through 2030. Available online: https:/ / www.diva-portal.org/smash/get/diva2:1074624/FULLTEXT01.pdf (accessed on 18 January 2022).

49. Pearson, M.M. 3-Local Government and Firm Innovation in China's Clean Energy Sector. In Policy, Regulation and Innovation in China's Electricity and Telecom Industries; Brandt, L., Rawski, T.G., Eds.; Cambridge University Press: Cambridge, UK, 2019.

50. Popp, D. Promoting Clean Energy Innovation at the State and Local Level. In Agricultural and Resource Economics Review. Vol. 49, Special Issue 2: Environmental Regulation and Innovation in Local Communities; Alzahrani, F., Collins, A.R., Eds.; Cambridge University Press: Cambridge, UK, 2020.

51. Niedbalska, G. Community Innovation Survey. In Innowacje i Transfer Technologii. Słownik Pojęć; Matusiak, K.B., Ed.; Polska Agencja Rozwoju Przemysłu: Warsaw, Poland, 2008; p. 47. Available online: https://www.parp.gov.pl/files/74/81/194/4357.pdf (accessed on 7 December 2021).

52. Instytut Polityki Energetycznej im. Ignacego Łukasiewicza. Regulamin Ogólnopolskiego Konkursu dla Jednostek Samorządu Terytorialnego na Najbardziej Innowacyjny Energetycznie Samorząd. 2021. Available online: https://www.instytutpe.pl/ konkursjst/regulamin/ (accessed on 7 December 2021).

53. Gmina Przywidz w Liczbach. Polska w Liczbach; Główny Urząd Statystyczny: Warsaw, Poland, 2020. Available online: https: //www.polskawliczbach.pl/gmina_Przywidz (accessed on 13 December 2021).

54. Zimakowski, M. The form for submitting the application of the Przywidz commune to the research on energy innovativeness of Polish local governments. Unpublished work.

55. Mapa Dotacji UE. Eko Energia od Somonina aż po Przywidz. Available online: https://mapadotacji.gov.pl/projekty/789683/ (accessed on 13 December 2021).

56. Gmina Potęowo w Liczbach. Polska w Liczbach; Główny Urząd Statystyczny: Warsaw, Poland, 2020. Available online: https: //www.polskawliczbach.pl/gmina_Potegowo (accessed on 13 December 2021).

57. Kozioł, K. Application form for the commune of Potegowo to study the energy innovation of Polish local governments. Unpublished work.

58. Wyniki Badań Bieżacych; Główny Urząd Statystyczny: Warsaw, Poland. Available online: https://demografia.stat.gov.pl/ BazaDemografia/StartIntro.aspx (accessed on 13 December 2021).

59. Fijołek, K. The form for submitting the application of the Rzeszów commune to the research on energy innovativeness of Polish local governments. Unpublished work.

60. Urząd Miasta Rzeszowa. Integracja Różnych Form Publicznego Transportu Zbiorowego w Rzeszowie. Available online: https: //bip.erzeszow.pl/pl/332-wspolne-projekty-gminnych-jednostek-budzetowych-dofinansowane-ze-zrodel-zewnetrznych/42 09-program-operacyjny-polska-wschodnia-2014-2020/4226-integracja-roznych-form-publicznego-transportu-zbiorowego-wrzeszowie.html (accessed on 13 December 2021).

61. Skiba, M. The application form for the Katowice commune to study the energy innovation of Polish local governments. Unpublished work.

62. Local Government Innovation in the Energy Sector. Available online: https://fsr.eui.eu/local-government-innovation-in-theenergy-sector/ (accessed on 18 January 2022).

63. Danish Energy Agency. Strategisk Energiplanlægning. Oplæg fra Arbejdsgruppe KL-ENS; Danish Energy Agency: København, Denmark, 2010.

64. Local Energy Systems-An Important Piece of the New Energy Puzzle. Available online: https://smartcitysweden.com/localenergy-systems-an-important-piece-of-the-new-energy-puzzle/ (accessed on 18 January 2022).

65. SDG Wijk Ecodorp Boekel. Available online: https:/ / www.ecodorpboekel.nl/ (accessed on 19 January 2022). 
66. Dawson, J. Are ecovillages a solution to the coming energy famine? Permacult. Mag. 2006, 47, 47-48.

67. Connors, P.; McDonald, P. Transitioning communities: Community, participation and the transition town movement. Community Dev. J. 2011, 46, 558-572. [CrossRef]

68. Nowakowska, A. Regionalny system innowacji. In Innowacje i Transfer Technologii. Słownik Pojęć; Matusiak, K.B., Ed.; Polska Agencja Rozwoju Przemysłu: Warsaw, Poland, 2008; p. 302. Available online: https://www.parp.gov.pl/files/74/81/469/12812. pdf (accessed on 7 December 2021). 